NBER WORKING PAPER SERIES

\title{
ESTIMATING THE EFFECT OF CURRENCY UNIONS ON TRADE AND OUTPUT
}

\author{
Jeffrey A. Frankel \\ Andrew K. Rose \\ Working Paper 7857 \\ http://www.nber.org/papers/w7857
NATIONAL BUREAU OF ECONOMIC RESEARCH 1050 Massachusetts Avenue
Cambridge, MA 02138
August 2000

This paper was written for the conference on Currency Unions, organized by Alberto Alesina and Robert Barro, Hoover Institution, Stanford University, May 19-20, 2000. We thank Dani Rodrik for catching an error, and Romain Wacziarg and other conference participants for suggestions. The views expressed herein are those of the authors and not necessarily those of the National Bureau of Economic Research.

(C) 2000 by Jeffrey A. Frankel and Andrew K. Rose. All rights reserved. Short sections of text, not to exceed two paragraphs, may be quoted without explicit permission provided that full credit, including (C) notice, is given to the source. 
Estimating the Effect of Currency Unions on Trade and Output

Jeffrey A. Frankel and Andrew K. Rose

NBER Working Paper No. 7857

August 2000

JEL No. O4, F4, F11, F33

\begin{abstract}
Gravity-based cross-sectional evidence indicates that currency unions stimulate trade; crosssectional evidence indicates that trade stimulates output. This paper estimates the effect that currency union has, via trade, on output per capita. We use economic and geographic data for over 200 countries to quantify the implications of currency unions for trade and output, pursuing a two-state approach. Our estimates at the first stage suggest that belonging to a currency union more than triples trade with the other members of the zone. Moreover, there is no evidence of trade-diversion. Our estimates at the second stage suggest that every one percent increase in trade (relative to GDP) raises income per capita by roughly $1 / 3$ of a percent over twenty years. We combine the two estimates to quantify the effect of currency union on output. Our results support the hypothesis that the beneficial effects of currency unions on economic performance come through the promotion of trade, rather than through a commitment to non-inflationary monetary policy, or other macroeconomic influences.
\end{abstract}

Jeffrey A. Frankel

Kennedy School of Government

Harvard University

79 JFK Street

Cambridge, MA 02138-5801

and NBER

jeffrey_frankel@harvard.edu
Andrew K. Rose

Haas School of Business

University of California

Berkeley, CA 94720-1900

and NBER

arose@haas.berkeley.edu 


\section{Introduction: Why Should Currency Unions Affect Output?}

Proponents of currency unions tout them as the ultimate credible commitment to noninflationary monetary policy. Among the benefits frequently cited are enhanced central bank credibility, superior inflation performance, and deeper capital markets, all of which tend to raise productivity and hence output. This paper confirms that currency unions improve the performance of an economy. The channel we focus on, however, is the substantial stimulus to trade that a currency union gives to its members, rather than the macroeconomic and financial influences conventionally emphasized.

The paper attempts econometric estimation of the effects that currency unions have on the long-run level and rate of growth of real income, in a cross-section of countries. We proceed by investigating two relationships: the hypothesis that currency union stimulates trade among its constituent units, and the hypothesis that trade in turn stimulates output.

The paper is wholly empirical and presents three chief results. First, currency unions promote bilateral trade. Second, they also promote overall openness (measured as trade/GDP); there is no evidence that trade created among members of a currency union comes at the expense of a diversion of their trade away from non-members. Finally, by raising overall trade, currency unions also raise output. We also present one negative result, since we test and find no support

for the common argument that currency unions work through other channels, e.g., by enhancing the central bank's credibility and stabilizing the macroeconomy.

If the benefits of currency union result from monetary stability, the composition of a currency union does not matter, so long as the anchor currency is strong and stable. In our view, however, geography is highly relevant to the makeup of common currency areas. Countries tend naturally to trade more with large neighbors; thus the benefits to adopting the currency of a large 
neighbor, other things equal, will exceed the benefits to adopting the currency of a country that is smaller or more distant. We demonstrate this effect by estimating the benefits for a large crosssection of countries of adopting either the dollar or the euro.

In section 2 below, we estimate the effect of currency union on trade. Section 3 provides estimates of the effects of trade on output, taking into account the likely endogeneity of trade. It also provides tests for alternative effects of currency union on output. Section 4 estimates the effect of "dollarizing" or adopting the euro for individual countries. After some sensitivity analysis and caveats, the paper ends with a few brief conclusions. Some discussion and results are relegated to Appendices to save space.

\section{The Effects of Currency Union on Trade}

A popular argument against floating currencies -- albeit one that most academic economists have been skeptical of -- is that higher exchange rate variability creates uncertainty that discourages international trade and investment. Fixing the exchange rate eliminates this risk, and so encourages trade. Adopting a neighbor's currency as one's own is an extremely credible commitment to exchange rate stability and has the extra advantage of eliminating transactions costs; both effects should promote trade and investment. The objective of this section of the paper is to provide a quantitative estimate of the effect of currency union in trade promotion. (Appendix 1 provides a description of how this paper fits into the literature more broadly.)

One reason is that academic economists have tended to downplay this argument is that much exchange rate risk can be hedged at low cost, through the use of the forward exchange contracts and other derivatives. Another reason is that there have been quite a few empirical 
studies of the effect of exchange rate volatility on both trade and investment; most find small or negligible effects. ${ }^{1}$ That is, it is difficult to estimate a relationship between exchange rate variability and trade using time-series data.

By way of contrast, cross-sectional approaches that use the "gravity" model have found a negative effect of bilateral exchange rate variability on bilateral trade in the 1960s and 1970s; Frankel and Wei (1995). ${ }^{2}$ Rose (2000) confirms these results and also shows that belonging to a common currency area has a large effect, multiplying trade by an estimated factor of over three. Evidently there is a discrete large benefit from eliminating transactions costs and possibility of future rate changes.

In the bare-bones gravity model, trade between a pair of countries is modeled as a positive function of their sizes (often both GDP and GDP per capita) and a negative function of the distance between the two countries. The model is one of the more successful empirical models in economics: typically a reasonable proportion of the variation in trade is explained with a model where the coefficients are economically sensible, and well-determined statistically. Frankel (1997), among many others, provides a more thorough review of the model. Since we are interested in estimating the effect of currency union on trade (and hence output), the gravity model is a natural vehicle to use.

\section{Gravity Estimates}

Table 1 reports the results of a number of different specifications of the gravity equation, augmented by different sets of controls. All specifications include the standard gravity regressors, and controls for common language, land border and membership in a regional free trade association. We are most interested in the coefficient on a dummy variable which is unity 
if the two countries belonged to a common currency area (such as Panama and the United States). The panel data set includes observations from almost 8,000 country-pair observations (from over 180 countries) at five-year intervals from 1970 through 1995. The standard errors reported are robust to clustered heterogeneity, and year-controls are included in the regression but not reported. The data set is described in more detail in the second appendix.

The models of Table 1 fit well, explaining over sixty percent of the variation in the data. The coefficients for the traditional gravity determinants are highly statistically significant, and economically sensible. The estimated coefficient on log distance is slightly over -1 , indicating that trade between a pair of countries falls by about one percent for every one percent increase in the distance between them. ${ }^{3}$ The coefficient on size (log real GDP) is around 0.8 , close to standard estimates. It indicates that trade rises with size but, holding constant for income per capita, the increase is a bit less than proportionate. The ratio of trade to output falls by 0.2 per cent for every 1 per cent increase in size, because large countries are more self-sufficient. Income per capita has its own estimated effect. The coefficient, around 0.6 indicates that rich countries trade proportionately more than the poor. An alternate description of the same estimate (holding constant for GDP) is that for every one per cent increase in the size of the population, the resulting greater self-sufficiency reduces openness by 0.6 per cent.

The coefficient on the dummy variable for a common language is around 0.7 , indicating that when two countries speak the same language, trade between them doubles. ${ }^{4}$ When they belong to a regional trading bloc, trade roughly triples, an estimate that is slightly higher than the literature's. ${ }^{5}$ When the pair share a common land border, trade rises by roughly 50 per cent. $^{6}$

The focus here is on the currency union coefficient, which is estimated at around 1.6. Some of the countries that use the currency of a larger country are also tied to it by other political 
and historical links that boost trade. We add dummy variables to represent current political unions (such as those between France and its overseas departments), historical colonial links to a mother country, and shared colonial experience. Each is highly significant statistically. The currency union coefficient gives up a little of its strength, falling to a still highly significant 1.2. This estimate implies that when two units share a common currency, trade is multiplied roughly three-fold $(\exp (1.2)=3.4)$, similar to the estimate in Rose (2000). Inspection of year-specific effects shows a small tendency for the coefficient to rise over time, between the 1970s and the 1990s. When extra geographic variables are added to the equation, they are usually significant, but do not much alter the size of the currency union effect. ${ }^{7}$ López-Cordova and Meissner (2000) provide consistent corroborating evidence from the gold standard period of the late nineteenth and early twentieth century.

A three-fold effect strikes those new to this literature as large, and indeed it is. But it is more plausible when one recalls the findings, for example, of McCallum (1995) and Helliwell (1998), that Canadian provinces are 12 to 20 times more inclined to trade with each other than with US states, after holding constant for distance and size. The latter finding has received much attention because it cannot be easily explained by geographic, linguistic, or trade policy variables. High on the list of possible reasons why integration is so much higher between provinces within a federation such as Canada than between countries is the fact that the provinces share a common currency. ${ }^{8}$

This massive bias towards domestic trade also characterizes our data set. ${ }^{9}$ Explaining such findings of "home bias" in goods market is a challenge for economists, and it is eminently plausible that some part of it is explained by the fact that trade across international borders usually entails trade between different monies. Our equations in effect show that the 
unexplained part of home bias can be reduced by measuring attributes that are shared by different areas both within and across countries, such as common language, common trade policy and so forth. They show that the currency union variable ranks in explanatory power roughly equal with the FTA variable, behind the colonial relationship, and ahead of common language and the residual political union effect. ${ }^{10}$

To check for the possibility that the stimulus to trade among members of a currency union comes at the expense of diversion of trade with non-members, we added a dummy variable that is unity when precisely one of the members of the pair belongs to a currency union. It turns out to show up with a statistically significant positive coefficient. Thus the evidence points toward trade creation rather than trade diversion, a point that we corroborate in Appendix 3 using aggregate (rather than bilateral) trade data.

The decision to form a currency union could be endogenous. Historical, political, and cultural links are known to promote bilateral trade. It is possible that those links, or the existing bilateral trade itself, could also give rise to the decision to adopt the partner's currency. That is why we hold constant for so many links -- linguistic, historical and political. Yet the currency union effect remains. Indeed, a surprisingly large number of former colonies have adopted the currency of a country other than that of the former colonial power. Moreover, Rose (2000) cites qualitative evidence and instrumental variable results suggesting that most currency unions were not in fact founded with the primary motive of promoting trade among their members.

\section{The Effect of Trade on Income}

In this section of the paper, we estimate the effect of trade on output. 
Classical trade theory gives us good reason to think that trade has a positive effect on the level of real income. New trade theory has made the field more realistic by introducing roles for increasing returns to scale, trade in imperfect substitutes, and endogenous technology. ${ }^{11}$ Some new trade theory also implies that open economies have higher growth rates, rather than just higher income levels, since interaction with foreigners spurs innovation by speeding up the absorption of new ideas.

Quite a few empirical studies of growth rates across countries find that the ratio of exports to GDP, or some other measure of openness, is a significant determinant of growth. ${ }^{12} \mathrm{~A}$ typical specification begins with the determinants of output suggested by neoclassical growth theory, and adds a variable for exports as a share of GDP. ${ }^{13}$ In such empirical work, openness typically seems to have a positive and significant effect on the growth rate.

Interpreting a significant correlation between trade and growth as implying causality from the former to the latter is potentially problematic however, because of the serious problem of simultaneity bias. Rodrik (1994b, p.2), for example, argues that the standard view "has backward the causal relationship between exports, on the one hand, and investment and growth on the other." The mechanism of reverse causality is eminently plausible and runs as follows: an exogenous increase in investment in a developing country with a comparative disadvantage in producing capital goods, necessitates an increase in imports of such goods (and, in turn, an increase in exports to pay for the imports). ${ }^{14}$ Similarly, Bradford and Chakwin (1993) argue that causality runs from investment to growth and exports, rather than the other way around. Helpman (1988, p.6) asks "Does growth drive trade, or is there a reverse link from trade to growth?"15 
A number of studies have tangled with the challenge posed by simultaneity. Many studies have sought to identify measures of trade policy, hoping that they are exogenous. ${ }^{16}$ But, aside from the serious difficulty of measuring trade policy, a fundamental conceptual problem of simultaneity still remains (e.g., Sala-i-Martin, 1991). What if free-market trade policies are no more important to growth than free-market domestic policies, but tend to be correlated with them? In this case, openness will be correlated with growth, even though trade does not cause growth. There have also been other attempts to solve the problem with mixed results. For instance, Jung and Marshall (1985), Hutchison and Singh (1987, 1992), and Bradford and Chakwin (1993) apply Granger-causality tests to the problem. Esfahani (1991) attempts a simultaneous equation approach. As so often in macro-econometrics, however, the simultaneity problem has remained largely intractable.

What is needed is a good instrumental variable, which is truly exogenous, and yet is highly correlated with trade. The gravity model offers a solution. Such variables as distance, populations, common borders, and common languages are plausibly exogenous. ${ }^{17}$ Yet these variables are highly correlated with trade, and thus make good instrumental variables. We use an intuitive two-step implementation of this idea. In the first stage, we estimate bilateral trade equations using the exogenous regressors in a gravity model. We then aggregate (the exponential of fitted trade) across a country's trading partners to create a prediction of its overall trade. In the second stage we use this predicted trade as an instrument for actual trade in an output equation. If trade still appears to be a significant determinant of output with instrumental variable estimates, then the effect of trade on output is plausibly causal.

This procedure has recently been implemented in Frankel and Romer (1999), who find that the effect of trade on output actually increases in magnitude after correcting for 
simultaneity. ${ }^{18}$ Irwin and Tervio (2000) have used the same technique on eight years ranging from 1913 through 1990 and similarly found (except for two interwar years) that the trade share has a highly significant effect on income with a magnitude comparable to that estimated by Frankel and Romer.

\section{The output equation}

The convergence hypothesis in the growth literature dictates that income at the end of a period depends on income at the beginning of the period, with a tendency to regress gradually toward some long-run steady state. Convergence is conditional if it is only present after conditioning on variables such as factor accumulation. ${ }^{19,20}$

While we consider a number of variants, our basic specifications are encompassed within:

$$
\begin{aligned}
& \ln (\mathrm{Y} / \mathrm{Pop})_{90, \mathrm{i}}=\alpha_{0}+\alpha_{1} \log (\mathrm{Pop})_{\mathrm{i}}+\alpha_{2} \log (\text { Area })_{\mathrm{i}}+\beta([\mathrm{X}+\mathrm{M}] / \mathrm{Y})_{90, \mathrm{i}} \\
& +\gamma_{1}(\mathrm{I} / \mathrm{Y})_{\mathrm{i}}+\gamma_{2} \mathrm{n}_{\mathrm{i}}+\gamma_{3} \mathrm{School}_{\mathrm{i}}+\gamma_{4} \mathrm{School}_{\mathrm{i}}+\delta \ln (\mathrm{Y} / \mathrm{Pop})_{70, \mathrm{i}}+\mathrm{u}_{\mathrm{i}}
\end{aligned}
$$

where: the dependent variable is the natural logarithm of GDP (Y) divided by total population (Pop) at the end of 1990, measured in real PPP-adjusted dollars for country i; land area is a secondary measure of country size which we sometimes include and is denoted "Area"; aggregate exports, aggregate imports, and gross investment are denoted "X", "M" and "I" respectively; the growth rate of population is denoted "n"; School1 and School2 are estimates of human capital investment based, respectively, on primary and secondary schooling enrollment rates; Greek letters denote coefficients; and " $u$ " denotes the residual impact of other, hopefully orthogonal influences. Variables other than GDP per capita and openness are computed as 
averages over the sample period. Mankiw, Romer, and Weil (1992) provide theory and a test of this equation without the openness term. The coefficient of interest to us is $\beta$, the effect of openness on output.

We call "controls" the variables that derive from neoclassical growth theory and appear on the second line of the equation: initial output, investment, human capital and population growth. Frankel and Romer (1999) and Irwin and Tervio (2000) adopt a more stripped-down specification by omitting these controls. They simply regressed output per capita against openness and two measures of country size, population and land area. Following, e.g., Hall and Jones (1999), their argument was that the factor accumulation variables might be endogenous. In this case, including these variables in the output equation might result in a downward-biased estimate of $\beta$ since some of the effect of openness may arrive via factor accumulation. Of course, inappropriately excluding these variables would also produce biased results and could be expected improperly to attribute too large an effect to trade. Consequently we estimate (1) both with and without controls and try to be conservative in our interpretation. ${ }^{21}$

\section{OLS results}

We begin by estimating our output equation with OLS to replicate the common finding that there is a statistical association between trade and income. In Table 2, we report OLS estimates of the impact of trade on output both with and without factor accumulation controls (the natural logarithm of population [and sometimes that of area] is included in both cases). We measure openness as the ratio of trade to output in levels, corresponding to the norm in the growth literature (the log case is handled in Appendix 3 which also uses a different IV approach). 
The key estimate in the income equation, the coefficient of openness, is positive, statistically significant, and economically large whether we include controls (in which case the coefficient is .33) or not (.79). ${ }^{22}$ Population, our default measure of size, has a positive and statistically significant influence whether we include controls or not, confirming that larger countries are better able to take advantage of scale economies and/or resource diversity.

As already noted, the openness variable may be standing in for factor accumulation variables or other national characteristics and initial conditions less easily measured. We want to hold constant for variables such as investment, knowing that we run the risk of then failing to give credit to openness for some effect on income that comes via factor accumulation. ${ }^{23}$ When initial GDP, along with other standard growth controls, is included, its coefficient is a highly significant 0.71 , representing a plausible degree of conditional convergence.

The key effect of interest is the coefficient on trade, which is a significant 0.33 in the OLS version. This says that, holding constant for 1970 income, income in 1990 was $1 / 3$ per cent higher for every 1.0 percentage point increase in the trade/GDP ratio. As expected, this effect is less than when we did not control for initial income. When multiplied by 3.45 (=1/(1.71)) to convert to an estimated effect on long-run income, the effect on output is 1.14 per cent for every 1.0 percentage point increase in openness. ${ }^{24}$ Parenthetically, the effects of investment and both schooling variables are statistically significant and reasonable; population growth has the hypothesized negative sign, but as in earlier work is the one neoclassical growth determinant that is not statistically significant. ${ }^{25}$ 


\section{Instrumental Variable Results}

The next step is to estimate the corresponding output equation estimates using instrumental variables estimation to account for the possible endogeneity of openness. The instrumental variables we choose are the specific predictions of bilateral trade from a simple gravity model which uses as controls: the log of distance, the log of partner country population, the log of area, and dummy variables for currency union, common language, common land border, regional FTA, landlocked status, and island status. After estimating the gravity model, we aggregate the exponent of the fitted values across bilateral trading partners to arrive at an estimate of total trade for a given country. We then divide estimated total trade by domestic GDP to obtain predicted openness.

This paper's two-step exercise would not be compelling if the correlation between countries' actual trade/GDP ratios and the numbers predicted by the gravity model were low. The correlation is of interest whether one is focused on the instrumental variables test of the effect of trade on output, or the two-stage point estimate of the effect of currency unions per se. As an exercise designed to eliminate the simultaneity problems in output equations, the exercise is only as good as the instrumental variables. Thus it is reassuring that the correlation between actual trade shares and the numbers obtained from aggregating the exponents of estimated bilateral $\log$ equations is .72 .

As Table 2 reports, the estimate of interest to us is $\beta$, the coefficient on openness. The results are sensitive to the particular perturbation of variables, as they should be. When we do not include controls, the coefficient is estimated to be 1.22 , statistically significant and economically important. When we include controls, the effect of trade on output remains at 33 . The implied steady state impact is $1.18(=.33 /(1-.72))$, which agrees remarkably well with the 
coefficient estimated when not controlling for initial income. This effect is economically large, statistically significant and quite close to the estimate without controls. However, to be conservative, we use .33 in our calculations below, our estimate of the effect of trade on output over a 20 -year period.

Table 2 also shows that adding the log of land area as another measure of country size does not destroy the finding of a large effect of openness on output (and land area only enters positively in the version without controls, where its coefficient is insignificantly different from zero).

\section{Does Currency Union have a Direct Effect on Output?}

Thus far we have assumed that currency unions affect output through their effect on openness. But might currency unions have a direct effect on output? There are at least two reasons to examine this issue. The less important is to allow for the possibility of an effect from economic interactions along geographic lines that are not necessarily intermediated by trade per se. The more important motivation is to allow the possibility of a currency union effect of an entirely different sort. In most of the literature on currency unions (e.g., Alesina and Barro, 2000), the advantage that is emphasized is not the convenience to importers and exporters of

abolishing currency distinctions. Rather the emphasis is on the credibility benefits derived when the central bank "ties its hands" with a rigid institutional commitment to monetary stability. ${ }^{26}$ Many of these models imply that the choice of an anchor currency for a small country to adopt doesn't matter, so long as it is a strong and stable currency (and perhaps experience similar business cycle shocks). In this view, there is not necessarily an advantage in choosing the currency of a country that is a natural partner because it is located nearby. In our trade-based 
approach, on the other hand, it should make a big difference with whom one forms a currency union.

We check this by including measures of currency union in the output equation. We do this in a number of different ways that are designed to capture the enhancement of trade or other economic interactions with partners.

First we add to the output equation in Table 2 a dummy variable that is unity if the country was a member of a common currency area in 1990, and zero otherwise. The results, shown in Table 2, indicated that the effect of currency unions is significantly negative when we omit controls, and small negative and insignificantly different from zero if we include controls. Apparently currency union in and of itself does not raise output by e.g., improving credibility and monetary stability.

Table 3 contains more advanced results. First, at the extreme left-hand side we model output as a simple function of size: the log of population. We then add to this equation a dummy variable that is unity if the country was a member of a common currency area in 1990, and zero otherwise. This negative result likely stems from the fact that a simple dummy variable for currency union membership does not take account of how many countries are in the currency union and how important they are to the domestic country. Thus we also include the inner product of bilateral currency union membership (since, e.g., Panama is in a common currency area with the United States but not the CFA franc zone countries), interacted with different measures of the importance of the bilateral partners. The importance of the bilateral partners in a currency union can be measured by the key determinants of bilateral trade such as size and proximity. Throughout, we omit openness and other controls, and estimate the equation with OLS. 
The results in Table 3, show that a country does not derive an income advantage from belonging to a currency union per se. Not only is the coefficient negative, but it is statistically different from zero. The importance of a country's currency union partners should not be forgotten. We begin by entering the inner product of bilateral currency union membership and the real GDP of the bilateral trading partner that is, we add $\sum_{j} C U_{i j} Y_{j}$ where $\mathrm{CU}_{\mathrm{ij}}$ is unity if countries $i$ and $j$ were in a common currency area, and zero otherwise; $Y_{j}$ denotes the real GDP of country $j$. A high value of this inner product indicates that country $i$ is in a currency union with countries which are economically large; we expect this to augment the trade and hence output of country i accordingly.

The inner product does indeed have has an economically and statistically significant positive effect on income. Since our gravity estimates indicate that trade not only depends on partner output, but also on the reciprocal of distance, we also try the aggregate ratio of union partners' output to distance, i.e., $\sum_{j} C U_{i j}\left(Y_{j} / D i s t_{i j}\right)$ where Dist $\mathrm{ij}_{\mathrm{ij}}$ is the natural logarithm of the distance between countries $\mathrm{i}$ and $\mathrm{j}$. Again the coefficient is large, positive and significant. Finally, since the partners' per capita income is also an important determinant of trade, we multiply the preceding variable by the square root of the aggregate per capita income of the currency union partners, that is we use $\sum_{j} C U_{i j}\left(Y_{j} / D i s t_{i j}\right) \sqrt{(Y / P o p)_{j}}$. The results are virtually unchanged. $^{27,28}$

If the currency union dummy had worked in the output equation regardless whether the union partner was important or not, it would have suggested that the benefits come through the central bank credibility route. ${ }^{29}$ Our evidence instead supports the notion that the currency union effect on output comes through the trade route. There is little support here for the notion that belonging to a currency union per se is good for output regardless of the partner. It matters 
whether the currency union includes important trade partners. That is, this reduced-form version of the output equation, where the currency union enters in a way specifically calculated to reflect bilateral trade, confirms the conclusion of our two-step approach: a country boosts its income when it adopts the currency of natural trading partner, one that has high income, and is preferably close as well. ${ }^{30}$

\section{The Effects of Currency Unions on Output}

In this section we try to put together the estimates of the two stages -- the effect of currency union on trade, and the effect of trade on output -- to estimate the effect of currency unions on output.

One way to proceed would be to estimate the effect of currency union on an average country's trade, and the effect of this additional trade on an average country's output. While we pursue this tack in Appendix 3 and find that the average effect of a currency union on output is about $4 \%$, we do not consider this calculation to be of great interest. ${ }^{31}$ The effect of currency union on openness depends on which other countries are in the currency union. The boost to trade (and therefore output) will be stronger if the partner is one with whom one trades, because it is large, nearby, or because of other (e.g., linguistic or historical) links. Lithuania will presumably boost its total trade and output more by adopting the euro than by adopting the New Zealand dollar.

Table 4 provides the answers, for each country in our sample, to two questions of interest: "What is the estimated effect on trade and output of adopting the dollar as the legal currency?" and "What would be the predicted effect of adopting the euro?" We exploit our 
bilateral gravity estimate, which predicts that a currency union boosts trade roughly three-fold with other countries that use the currency in question.

The first column in Table 4 reports the country's 1995 openness ratio, trade as a percentage of GDP. ${ }^{32}$ The second and third columns show the shares of trade that the country conducted, with the dollar zone (the United States and countries which use the dollar such as Panama) and the euro-11 zone respectively. ${ }^{33}$ The next columns show what the effect would be if the country in question were to join the dollar or euro zones. In the table, we use our estimate that the formation of a currency union causes trade to grow three-fold between the currency union members. (The reader is welcome to substitute his or her own preferred estimate.) The fourth column shows what the overall openness ratio would rise to if there were a three-fold increase in trade conducted with the dollar zone; the fifth is the analogue for the euro zone. The last two columns report the predicted effect on income per capita. In this case we use our preferred IV estimate, that the effect on 1990 income was 0.33 per cent for every 1.0 percentage points in openness.

While one should view these estimates as illustrative, they are not without interest. We estimate, for example, that Albania would benefit far more from the trade effects of adopting the euro (an estimated 23 per cent boost to income over 20 years) than from "dollarizing" (an estimated 1 per cent boost). Because Albania's natural trading partners are in Europe, a tripling of its trade with the euro block does far more for its overall trade than does "dollarization". Similarly, El Salvador gains far more from dollarizing than from joining the euro bloc. ${ }^{34,35}$

\section{Sensitivity of the Results With Respect to the Inclusion of Small Countries}


Canada's proximity and naturally high level of trade with the United States mean that adopting the US dollar would boost trade and output far more for Canada than going on the euro. Still, for Canada and a number of other countries, the effects estimated in Table 4 are implausibly large. In this section, we consider the possibility that some of the estimates are inapplicable to larger countries. Our intuition tells us that income may depend non-linearly on size and trade (even in logs). Perhaps a country needs access to a market that is of at least a certain threshold size, after which the benefits of economies of scale are no longer so large. Not only might allowing for such nonlinearities help produce estimates more relevant to the larger countries, but an estimated threshold for economic size would be useful information for small territories and countries that are contemplating entering or leaving currency unions or political unions. These points are especially telling since most members of currency unions were small until European Monetary Union in 1999 (for which data are not yet available).

We have tried a simple test for nonlinearity in our estimated relationships, specifically a threshold effect regarding the size of the market. ${ }^{36}$ One suspects that such tiny units as Gibraltar, Gaza, and Guam, are not economically viable on their own, and are highly dependent on international trade. If a country makes it past a certain threshold in size, perhaps it is no longer so dependent on trade? However, when we split the sample in half according to the size of the population, we found that openness was no less beneficial for output in the large countries than in the small ones.

We also examined the trade equation, and found that currency unions were no less beneficial to bilateral trade in large countries than in small ones. Specifically, when we dropped small countries (those more than two standard deviations below the average size), the currency union coefficient remained a highly significant 1.6. When we dropped all countries more than 
one standard deviation below the average size, the currency union coefficient stayed a highly significant 1.9. The results are also robust to omitting observations where the product of the sizes (defined as either population or GDP) is especially small, or where the difference is especially large. We have also tried adding a quadratic term for openness in the output equation, but it was not statistically significant. Thus we have so far found no evidence that the relationships are very sensitive with respect to size.

It has been suggested that the statistical relationship across countries between openness and output may be sensitive to the inclusion of a few outliers, particularly Luxembourg, Hong Kong, and Singapore, which all have very high ratios of trade to GDP. ${ }^{37}$ When we exclude outliers in general (observations with residuals which are more than two standard deviations of either sign) the results are little affected. We also tried excluding specifically the observations for Luxembourg, Hong Kong, and Singapore from the output equation. When this is done in our

preferred version of the IV estimation, the results are little affected. In particular, the coefficient on openness remains statistically significant. Its point estimate is 6.33 when we condition only on country size, and 0.16 when we condition also on initial income and the other factors. ${ }^{38}$

Our sensitivity analysis provides us with little reason to believe our results stem solely from the small countries in our sample.

\section{Qualifications}

We have found large estimates of the effects of currency unions on trade and of the resulting trade on output. There are three major reasons why we are not prepared to assert that a member of EMU, for example, will necessarily experience an immediate surge in trade and output in the magnitude of our estimates. 
First, it is possible that an element of endogeneity remains in the currency union variable, notwithstanding that we have controlled for such factors as common language, colonial history, political union, and so on.

Second, as we have noted, our data on currency unions comes from small countries, and may not be applicable to large countries, for example because all the gains to intra-currency trade have been exhausted internally. We have found no evidence of nonlinearity using different tests (dividing the sample by size, and entering quadratic terms). But if currency unions among large countries behave completely differently from unions among small countries, we have no way of knowing it from our data.

Third, we have not yet provided any evidence regarding time lags of the effects of currency unions on trade patterns. Thus we do not know how long it may take to attain the large effects that we estimate in cross-section data. ${ }^{39}$

\section{Summary of Conclusions}

Scale is important to an economy, whether it is attained by the intrinsic size of the political unit, by political union with a larger country, or by international trade. In the latter case, the evidence is increasingly clear that currency unions provide a significant stimulus to trade. But it matters with whom one enters a currency union. The literature on exchange rate regimes with its focus on central bank credibility implies that the crucial requirement for a currency partner is that the currency be stable in value. Our results suggest that the currency should belong to a country or countries that are natural trading partners, by virtue of size, proximity, and/or other linkages. 
Using a large data set of economic and geographic variables for over 200 countries and dependencies, we have tried to quantify the implications of currency unions for trade and output using a two-stage approach. Our results at each stage have been significant statistically and economically. Our estimates at the first stage suggest that a currency union more than triples trade with the partners in question. Furthermore, there is no evidence of diversion of trade away from non-members. Thus the currency union boosts total trade. Our estimates at the second stage suggest that every one percent increase in trade (relative to GDP) raises income per capita by roughly $1 / 3$ of a per cent over a 20 -year period, and by substantially more over the long run. We put the two estimates together to estimate the effect of a currency union on output. Our results suggest that, for a country like Ecuador or El Salvador that conducts half its trade with the United States, a tripling of trade with this major partner as the result of official "dollarization" could boost income per capita as much as 19 per cent over 20 years. Similarly, the estimates suggest that Poland could raise its income as much as 20 per cent by joining the euro zone.

These results are subject to many caveats. We don't yet know how quickly countries reap the trade-boosting effects of currency unions. We don't know if the same effects that we have estimated for a collection of mostly small countries can be extended to large countries. And despite our attempts to hold constant for a number of factors, we don't know if our currency union variable might still be appropriating some of the influence of cultural or historical links that we have yet to measure. It is also possible that some of the output effect comes through other geographic interactions that also run along gravity lines. Still, we find it reassuring that the currency union has an effect on income when included directly in the income equation, if and only if it is weighted by the importance of trading partners. This suggests that the benefit does 
not come from monetary stability. And we have found no evidence that currency union per se has a positive significant effect on output.

Finally we should make it clear that we have not concerned ourselves with most arguments for or against currency unions -- for example, that the loss of monetary independence will make it impossible to respond to shocks. We have simply quantified one potential benefit of currency unions that we consider to have been under-examined in the literature but large. 


\section{References}

Alesina, Alberto, Enrico Spolaore and Romain Wacziarg, 1999, "Economic Integration and Political Disintegration," Dec. Revised version of NBER Working Paper no. 6163, September 1997. Forthcoming, American Economic Review.

Alesina, Alberto and Robert Barro, 2000, "Currency Unions” unpublished.

Barro, Robert, 1991, "Economic Growth in a Cross Section of Countries," Quarterly Journal of Economics, May.

Barro, Robert, and Xavier Sala-i-Martin, 1992, "Convergence," Journal of Political Economy.

Bhagwati, Jagdish, 1988, "Export Promoting Trade Strategy: Issues and Evidence," World Bank Research Observer, Jan. 3, no.1, 27-57.

Bradford, Colin, Jr., 1994, From Trade-Driven Growth to Growth-Driven Trade: Reappraising the East Asian Development Experience, Organization for Economic Cooperation and Development, Paris.

Bradford, Colin, Jr, and Naomi Chakwin, 1993, "Alternative Explanation of the Trade-Output Correlation in the East Asian Economies," OECD Development Centre Technical Papers No. 87, Paris (August).

DeLong, Bradford, and Lawrence Summers, 1991, "Equipment Investment and Economic Growth," Quarterly Journal of Economics 56, 2, 445-502.

Dollar, David, 1992, "Outward-oriented Developing Economies Really Do Grow More Rapidly: Evidence from 95 LDCs: 1976-1985," Economic Development and Cultural Change 40, 523 544.

Edison, Hali, and Michael Melvin, 1990, "The Determinants and Implications of the Choice of An Exchange Rate System," in Monetary Policy For a Volatile Global Economy, W. Haraf and T. Willett, eds., American Enterprise Institute, Washington, D.C..

Edwards, Sebastian, 1993a, "Openness, Trade Liberalization and Growth in Developing Countries," Journal of Economic Literature, Sept. 31, no. 3, 1358-93.

Edwards, Sebastian, 1993b, "Trade Policy, Exchange Rates, and Growth," in R. Dornbusch and S. Edwards, eds., Reform, Recovery and Growth: Latin America and the Middle East, Chicago, University of Chicago Press, 13-49, 1995.

Engel, Charles, and John Rogers, "How Wide is the Border?" American Economic Review 86, no.5, December 1996, 1112-1125 
Engel, Charles, and John Rogers, 1998. "Regional Patterns in the Law of One Price: The Role of Geography vs. Currencies," in J. Frankel, ed., The Regionalization of the World Economy, Chicago, University of Chicago Press.

Esfahani, Hadi, 1991, "Exports, Imports, and Economic Growth in Semi-Industrialized Countries," Journal of Development Economics, January, 35, no.1, 93-116.

Feder, Gershon, 1982, "On Exports and Economic Growth," Journal of Development Economics, Feb./Apr., 12, no. 1, 59-73.

Fischer, Stanley, 1991, "Growth, Macroeconomics and Development," on O. Blanchard and S. Fischer, eds., NBER Macroeconomics Annual 1991, MIT Press, 329-64.

Fischer, Stanley, 1993, “The Role of Macroeconomic Factors in Growth," Journal of Monetary Economics, Jan. 32, no. 3, 485-512.

Frankel, Jeffrey, 1997, Regional Trading Blocs, Institute for International Economics, Washington DC.

Frankel, Jeffrey, and David Romer, 1999, "Does Trade Cause Growth?" American Economic Review 89, no. 3, June 1999, 379-399.

Frankel, Jeffrey, and Shang-Jin Wei, 1995, "Emerging Currency Blocs," in The International Monetary System: Its Institutions and its Future, edited by Hans Genberg, Springer, Berlin, 111143.

Ghosh, Atish, Ann-Marie Gulde, and Holger Wolf, 1997, "Currency Boards - The Better Peg?", IMF Working Paper.

Goldstein, Morris, 1995, The Exchange Rate System and the IMF: A Modest Agenda, Policy Analyses in International Economics 39, June, Institute for International Economics.

Grossman, Gene, and Elhanan Helpman, 1991a, Innovation and Growth in the Global Economy, MIT Press: Cambridge.

Grossman, Gene, and Elhanan Helpman, 1991b, "Trade, Knowledge Spillovers, and Growth," European Economic Review 35, no. 2-3, April, 517-526.

Robert Hall and Charles Jones, 1999, "Why Do Some Countries Produce So Much More Output per Worker than Others?" Quarterly Journal of Economics, Feb., 114, no.1, 83-116.

Helpman, Elhanan. 1987. "Imperfect Competition and International Trade: Evidence from Fourteen Industrial Countries," Journal of the Japanese and International Economies 1: 62-81.

Helpman, Elhanan. 1988, "Growth, Technological Progress, and Trade," National Bureau of Economic Research Reprint no. 1145. 
Helpman, Elhanan and Paul Krugman. 1985. Market Structure and Foreign Trade, Cambridge, MIT Press.

Helliwell, John, 1998, How Much Do National Borders Matter? Brookings Institution: Washington DC.

Hutchison, Michael, and Nirvikar Singh, 1992, "Exports, Non-Exports, and Externalities: A Granger Causality Approach," International Economic Journal 6, no.2, 79-94.

Irwin, Douglas, and Marko Tervio, 2000, "Does Trade Raise Income? Evidence from the Twentieth Century," preliminary draft, March.

Jung, Woo, and Peyton Marshall, 1985, "Exports, Growth, and Causality in Developing Countries, " Journal of Development Economics 18, 1-12.

Kohli, Inderjit, and Nirvikar Singh, 1989, "Exports and Growth: Critical Minimum Effort and Diminishing Returns," Journal of Development Economics, April, 30, no. 2, 391-400.

Krueger, Anne, 1978, Foreign Trade Regimes and Economic Development: Liberalization Attempts and Consequences, Ballinger for National Bureau of Economic Research.

Levine, Ross, and David Renelt, 1992, "A Sensitivity Analysis of Cross-Country Growth Regressions," American Economic Review 82, no. 4, 942-963.

Linneman, Hans. 1966. An Econometric Study of International Trade Flows, North-Holland, Amsterdam.

López-Cordova, Ernesto and Chris Meissner (2000) "Exchange-Rate Regimes and International Trade: Evidence from the Classical Gold Standard Era" UC Berkeley manuscript.

Mankiw, N. Gregory, David Romer and David Weil, 1992, "A Contribution to the Empirics of Economic Growth," Quarterly Journal of Economics 107, 407-437.

McCallum, John, 1995, "National Borders Matter: Canada-U.S. Regional Trade Patterns," American Economic Review 85, no.3, June, 615-623.

Michaely, Michael, 1977, "Exports and Growth: An Empirical Investigation," Journal of Development Economics March, 4, no.1, 49-53.

Quah, Danny, and James Rauch, 1990, "Openness and the Rate of Economic Growth," Working Paper, University of California, San Diego, Oct.

Rodrik, Dani, 1994b, "Getting Interventions Right: How South Korea and Taiwan Grew Rich," 20th Panel Meeting of Economic Policy; NBER Working Paper No. 4964, December. 
Romer, Paul, 1989, "What Determines the Rate of Growth and Technical Change?" World Bank Working Paper No. 279.

Rose, Andrew, 2000, “One Money, One Market? The Effect of Common Currencies on International Trade," Economic Policy.

Sala-i-Martin, Xavier, 1991, "Comment," NBER Macroeconomics Annual 6, 368-378.

Summers, Robert, and Alan Heston, 1988, "A New Set of International Comparison of Real Product and Price Levels: Estimates for 130 countries, 1950-85," Review of Income and Wealth 34, March, 1-26.

van den Berg, Hendrix, 1994, "Foreign Trade and Economic Growth: Time Series Evidence from Latin American," Journal of International Trade and Economic Development 3, no. 3, Nov., 249-268.

Wei, Shang-Jin. 1996. "How Stubborn Are Nation States in Globalization?" NBER Working Paper 5331. April. 
Table 1: The Effect of Currency Unions on Bilateral Trade, in the Gravity Model

\begin{tabular}{|c|c|c|c|c|}
\hline Currency Union & $\begin{array}{l}1.53 \\
(.18)\end{array}$ & $\begin{array}{l}1.22 \\
(.19)\end{array}$ & $\begin{array}{l}1.59 \\
(.18)\end{array}$ & $\begin{array}{l}1.72 \\
(.18)\end{array}$ \\
\hline Log Distance & $\begin{array}{l}-1.09 \\
(.03)\end{array}$ & $\begin{array}{l}-1.09 \\
(.03)\end{array}$ & $\begin{array}{l}-1.07 \\
(.03)\end{array}$ & $\begin{aligned}-1.11 \\
(.03)\end{aligned}$ \\
\hline $\begin{array}{r}\text { Log Product Real } \\
\text { GDP }\end{array}$ & $\begin{array}{l}.79 \\
(.01)\end{array}$ & $\begin{array}{c}.80 \\
(.01) \\
\end{array}$ & $\begin{array}{c}.95 \\
(.01)\end{array}$ & $\begin{array}{r}.80 \\
(.01) \\
\end{array}$ \\
\hline $\begin{array}{r}\text { Log Product Real } \\
\text { GDP/capita }\end{array}$ & $\begin{array}{c}.64 \\
(.01)\end{array}$ & $\begin{array}{c}.66 \\
(.01)\end{array}$ & $\begin{array}{c}.46 \\
(.02)\end{array}$ & $\begin{array}{l}.63 \\
(.02)\end{array}$ \\
\hline $\begin{array}{r}\text { Common } \\
\text { Language }\end{array}$ & $\begin{array}{c}.73 \\
(.06)\end{array}$ & $\begin{array}{c}.44 \\
(.06)\end{array}$ & $\begin{array}{l}.76 \\
(.06)\end{array}$ & $\begin{array}{l}.69 \\
(.06)\end{array}$ \\
\hline $\begin{array}{r}\text { Common Land } \\
\text { Border }\end{array}$ & $\begin{array}{c}.37 \\
(.12)\end{array}$ & $\begin{array}{c}.43 \\
(.12)\end{array}$ & $\begin{array}{c}.62 \\
(.13)\end{array}$ & $\begin{array}{l}.39 \\
(.12)\end{array}$ \\
\hline Common FTA & $\begin{array}{l}1.31 \\
(.11)\end{array}$ & $\begin{array}{l}1.25 \\
(.10)\end{array}$ & $\begin{array}{l}1.16 \\
(.11)\end{array}$ & $\begin{array}{l}1.28 \\
(.11)\end{array}$ \\
\hline $\begin{array}{l}\text { Common } \\
\text { Colonizer }\end{array}$ & & $\begin{array}{c}.65 \\
(.08)\end{array}$ & & \\
\hline Political Union & & $\begin{array}{l}1.08 \\
(.35)\end{array}$ & & \\
\hline $\begin{array}{r}\text { Ex- } \\
\text { Colony/Colonizer }\end{array}$ & & $\begin{array}{l}2.19 \\
(.12)\end{array}$ & & \\
\hline $\begin{array}{l}\text { Number of } \\
\text { landlocked in pair } \\
(0,1 \text { or } 2)\end{array}$ & & & $\begin{array}{l}-.36 \\
(.04)\end{array}$ & \\
\hline $\begin{array}{r}\text { Number of islands } \\
\text { in pair }(0,1 \text { or } 2)\end{array}$ & & & $\begin{array}{c}.04 \\
(.04)\end{array}$ & \\
\hline $\begin{array}{r}\text { Log of Product of } \\
\text { Land Area } \\
\end{array}$ & & & $\begin{array}{l}-.16 \\
(.01) \\
\end{array}$ & \\
\hline $\begin{array}{r}\text { Currency } \\
\text { Union/Non Union }\end{array}$ & & & & $\begin{array}{l}.37 \\
(.04)\end{array}$ \\
\hline $\mathbf{R}^{2}$ & .62 & .63 & .64 & .63 \\
\hline RMSE & 2.03 & 2.00 & 1.99 & 2.02 \\
\hline
\end{tabular}

Regressand is log of bilateral trade in real American dollars.

Number of Observations $=31,101$.

Year-specific fixed effects not reported.

Robust standard errors recorded in parentheses. 
Table 2: The Effect of Openness on GDP/capita

\begin{tabular}{|c|c|c|c|c|c|c|c|c|}
\hline & OLS & IV & IV & IV & OLS & IV & IV & IV \\
\hline Openness & $\begin{array}{l}.79 \\
(.18)\end{array}$ & $\begin{array}{l}1.22 \\
(.56)\end{array}$ & $\begin{array}{l}1.27 \\
(.69)\end{array}$ & $\begin{array}{l}1.09 \\
(.52)\end{array}$ & $\begin{array}{l}.33 \\
(.07)\end{array}$ & $\begin{array}{l}.33 \\
(.08)\end{array}$ & $\begin{array}{l}.17 \\
(.08)\end{array}$ & $\begin{array}{l}.32 \\
(.09)\end{array}$ \\
\hline Log Population & $\begin{array}{l}.14 \\
(.06)\end{array}$ & $\begin{array}{l}.19 \\
(.09)\end{array}$ & $\begin{array}{l}.18 \\
(.10)\end{array}$ & $\begin{array}{l}.12 \\
(.09)\end{array}$ & $\begin{array}{l}.07 \\
(.02)\end{array}$ & $\begin{array}{l}.07 \\
(.03)\end{array}$ & $\begin{array}{l}.10 \\
(.03)\end{array}$ & $\begin{array}{l}.06 \\
(.09)\end{array}$ \\
\hline Log Area & & & $\begin{array}{l}.02 \\
(.10)\end{array}$ & & & & $\begin{array}{l}-.06 \\
(.03)\end{array}$ & \\
\hline Currency Union & & & & $\begin{array}{l}-.86 \\
(.25)\end{array}$ & & & & $\begin{array}{l}-.07 \\
(.09)\end{array}$ \\
\hline $\begin{array}{r}\text { Log'70 Real } \\
\text { GDP/capita }\end{array}$ & & & & & $\begin{array}{l}.71 \\
(.05)\end{array}$ & $\begin{array}{l}.72 \\
(.06)\end{array}$ & $\begin{array}{l}.75 \\
(.05)\end{array}$ & $\begin{array}{l}.72 \\
(.06)\end{array}$ \\
\hline Investment Ratio & & & & & $\begin{array}{c}.016 \\
(.006)\end{array}$ & $\begin{array}{c}.015 \\
(.006)\end{array}$ & $\begin{array}{c}.018 \\
(.006)\end{array}$ & $\begin{array}{c}.015 \\
(.006)\end{array}$ \\
\hline $\begin{array}{r}\text { Population Growth } \\
\text { Rate }\end{array}$ & & & & & $\begin{array}{l}-.06 \\
(.05)\end{array}$ & $\begin{array}{l}-.05 \\
(.06)\end{array}$ & $\begin{array}{l}-.04 \\
(.06)\end{array}$ & $\begin{array}{l}-.05 \\
(.06)\end{array}$ \\
\hline Primary Schooling & & & & & $\begin{array}{c}.002 \\
(.002)\end{array}$ & $\begin{array}{c}.002 \\
(.002)\end{array}$ & $\begin{array}{c}.002 \\
(.002)\end{array}$ & $\begin{array}{c}.002 \\
(.002)\end{array}$ \\
\hline Secondary Schooling & & & & & $\begin{array}{c}.007 \\
(.002) \\
\end{array}$ & $\begin{array}{c}.007 \\
(.003) \\
\end{array}$ & $\begin{array}{c}.006 \\
(.002)\end{array}$ & $\begin{array}{c}.007 \\
(.003)\end{array}$ \\
\hline $\begin{array}{r}\text { Number of } \\
\text { Observations }\end{array}$ & 115 & 108 & 107 & 107 & 106 & 101 & 101 & 101 \\
\hline $\mathbf{R}^{2}$ & .11 & .05 & .04 & .13 & .94 & .94 & .94 & .94 \\
\hline RMSE & 1.02 & 1.05 & 1.06 & 1.01 & .28 & .28 & .28 & .28 \\
\hline
\end{tabular}

Regressand is log of Real GDP/capita in 1990, PWT.

Intercepts not reported. Robust standard errors recorded in parentheses.

Instrumental variable from aggregated fit of gravity equation. 
Table 3: The Effect of Currency Unions on GDP/capita

\begin{tabular}{|c|c|c|c|c|c|}
\hline Log Population & $\begin{array}{l}.04 \\
(.05)\end{array}$ & $\begin{array}{l}-.02 \\
(.08)\end{array}$ & $\begin{array}{l}-.02 \\
(.05)\end{array}$ & $\begin{array}{l}-.02 \\
(.05)\end{array}$ & $\begin{array}{l}-.02 \\
(.05)\end{array}$ \\
\hline Currency Union & & $\begin{array}{l}-.85 \\
(.25)\end{array}$ & $\begin{array}{l}-1.17 \\
(.23)\end{array}$ & $\begin{array}{l}-1.17 \\
(.23)\end{array}$ & $\begin{array}{l}-1.17 \\
(.22)\end{array}$ \\
\hline $\begin{array}{r}\text { Inner Product of Currency } \\
\text { Union and Real GDP* }\end{array}$ & & & $\begin{array}{l}2.21 \\
(.48)\end{array}$ & & \\
\hline $\begin{array}{r}\text { Inner Product of Currency } \\
\text { Union and (Real } \\
\text { GDP/Distance)** }\end{array}$ & & & & $\begin{array}{c}4.80 \\
(1.19)\end{array}$ & \\
\hline $\begin{array}{r}\text { Inner Product of Currency } \\
\text { Union and [(Real GDP/ } \\
\text { Dist. }) * \sqrt{\text { Real GDP } / \text { cap }]^{* * *}}\end{array}$ & & & & & $\begin{array}{l}3.71 \\
(.80)\end{array}$ \\
\hline $\begin{array}{r}\text { Test for Joint Significance of } \\
\text { both CU terms (p-value) }\end{array}$ & & & .00 & .00 & .00 \\
\hline Number of Observations & 115 & 114 & 107 & 107 & 107 \\
\hline $\mathbf{R}^{2}$ & .00 & .08 & .12 & .12 & .12 \\
\hline RMSE & 1.07 & 1.03 & 1.02 & 1.02 & 1.02 \\
\hline
\end{tabular}

Regressand is log of Real GDP/capita in 1990, PWT.

OLS. Intercepts not reported. Robust standard errors recorded in parentheses.

* Coefficient and standard error multiplied by $\mathrm{e}^{10}$

** Coefficient and standard error multiplied by $\mathrm{e}^{7}$

*** Coefficient and standard error multiplied by $\mathrm{e}^{9}$ 
Table 4: Estimated Effects of "Dollarization" and Euro-adoption on Trade and Growth

\begin{tabular}{|c|c|c|c|c|c|c|c|}
\hline & \begin{tabular}{|c|}
$\begin{array}{c}\text { Trade } \\
(\%\end{array}$ \\
GDP)
\end{tabular} & \begin{tabular}{|c|} 
\$ Zone \\
Trade (\% \\
Trade) \\
\end{tabular} & $\begin{array}{c}\text { Euro Zone } \\
\text { Trade (\% } \\
\text { Trade) } \\
\end{array}$ & $\begin{array}{c}\text { On Trade, } \\
\text { adopts } \$ \\
(\% \text { GDP) }\end{array}$ & $\begin{array}{c}\text { On Trade, } \\
\text { adopts } € \\
\text { (\% GDP) }\end{array}$ & $\begin{array}{c}\text { On GDP, } \\
\text { adopts \$ } \\
(\% \text { GDP) } \\
\end{array}$ & $\begin{array}{l}\text { On GDP, } \\
\text { adopts } € \\
(\% \text { GDP) } \\
\end{array}$ \\
\hline Albania & 47 & 3 & 75 & 50 & 117 & 1 & 23 \\
\hline Algeria & 59 & 13 & 62 & 74 & 131 & 5 & 24 \\
\hline Angola & 110 & 50 & 34 & 219 & 184 & 36 & 25 \\
\hline Argentina & 17 & 16 & 23 & 23 & 25 & 2 & 3 \\
\hline Australia & 42 & 14 & 12 & 54 & 52 & 4 & 3 \\
\hline Austria & 78 & 4 & 69 & 85 & 186 & 2 & 36 \\
\hline Bangladesh & 37 & 20 & 21 & 52 & 52 & 5 & 5 \\
\hline Belize & 103 & 44 & 8 & 194 & 119 & 30 & 5 \\
\hline Benin & 63 & 5 & 45 & 69 & 120 & 2 & 19 \\
\hline Bhutan & 77 & 3 & 13 & 82 & 97 & 1 & 7 \\
\hline Brazil & 15 & 23 & 24 & 21 & 22 & 2 & 2 \\
\hline Bulgaria & 103 & 5 & 56 & 114 & 217 & 4 & 38 \\
\hline Burkina Faso & 41 & 4 & 71 & 45 & 100 & 1 & 19 \\
\hline Burundi & 33 & 7 & 75 & 37 & 82 & 1 & 16 \\
\hline Cambodia & 80 & 2 & 8 & 84 & 93 & 1 & 4 \\
\hline Cameroon & 46 & 3 & 69 & 48 & 109 & 1 & 21 \\
\hline Canada & 73 & 76 & 5 & 184 & 81 & 36 & 3 \\
\hline Cent. Afr. Rep. & 49 & 2 & 72 & 50 & 119 & 1 & 23 \\
\hline Chad & 76 & 6 & 75 & 84 & 190 & 3 & 38 \\
\hline Chile & 55 & 21 & 17 & 79 & 75 & 8 & 6 \\
\hline China & 40 & 13 & 11 & 51 & 49 & 3 & 3 \\
\hline Colombia & 36 & 38 & 18 & 64 & 50 & 9 & 4 \\
\hline Comoros & 64 & 2 & 70 & 66 & 153 & 1 & 29 \\
\hline Congo D. R. & 59 & 13 & 57 & 75 & 126 & 5 & 22 \\
\hline Congo Rep. & 128 & 14 & 77 & 162 & 324 & 11 & 65 \\
\hline Costa Rica & 86 & 53 & 17 & 177 & 115 & 30 & 10 \\
\hline Cote d'Ivoire & 77 & 7 & 73 & 88 & 189 & 4 & 37 \\
\hline Denmark & 64 & 4 & 49 & 70 & 127 & 2 & 21 \\
\hline Djibouti & 99 & 3 & 38 & 104 & 173 & 2 & 24 \\
\hline Domin. Rep. & 63 & 76 & 7 & 158 & 72 & 31 & 3 \\
\hline Ecuador & 58 & 45 & 16 & 111 & 77 & 17 & 6 \\
\hline Egypt & 53 & 18 & 38 & 72 & 94 & 6 & 13 \\
\hline El Salvador & 59 & 50 & 14 & 118 & 76 & 19 & 5 \\
\hline Eqtl. Guinea & 154 & 21 & 45 & 220 & 291 & 22 & 45 \\
\hline
\end{tabular}




\begin{tabular}{|c|c|c|c|c|c|c|c|}
\hline Ethiopia & 38 & 12 & 53 & 47 & 78 & 3 & 13 \\
\hline Fiji & 115 & 10 & 4 & 137 & 125 & 7 & 3 \\
\hline Finland & 68 & 7 & 35 & 78 & 116 & 3 & 16 \\
\hline France & 45 & 6 & 56 & 50 & 95 & 2 & 17 \\
\hline Gabon & 93 & 46 & 33 & 179 & 154 & 28 & 20 \\
\hline Gambia & 132 & 2 & 51 & 138 & 267 & 2 & 45 \\
\hline Germany & 46 & 7 & 46 & 53 & 89 & 2 & 14 \\
\hline Ghana & 60 & 12 & 40 & 74 & 108 & 5 & 16 \\
\hline Greece & 43 & 7 & 64 & 49 & 99 & 2 & 18 \\
\hline Guatemala & 45 & 44 & 10 & 84 & 54 & 13 & 3 \\
\hline Guinea & 48 & 15 & 56 & 62 & 102 & 5 & 18 \\
\hline Guinea-Bissau & 47 & 2 & 73 & 49 & 115 & 1 & 23 \\
\hline Guyana & 211 & 28 & 12 & 330 & 260 & 39 & 16 \\
\hline Haiti & 36 & 67 & 13 & 85 & 46 & 16 & 3 \\
\hline Honduras & 91 & 52 & 17 & 186 & 122 & 31 & 10 \\
\hline Hong Kong & 303 & 16 & 10 & 400 & 366 & 32 & 21 \\
\hline Hungary & 76 & 4 & 71 & 82 & 183 & 2 & 35 \\
\hline Iceland & 67 & 11 & 34 & 82 & 113 & 5 & 15 \\
\hline India & 28 & 17 & 29 & 37 & 44 & 3 & 5 \\
\hline Indonesia & 52 & 13 & 15 & 65 & 67 & 4 & 5 \\
\hline Iran & 36 & 1 & 40 & 37 & 66 & 0 & 10 \\
\hline Ireland & 134 & 11 & 35 & 164 & 227 & 10 & 31 \\
\hline Israel & 69 & 25 & 38 & 104 & 121 & 11 & 17 \\
\hline Italy & 51 & 6 & 51 & 58 & 103 & 2 & 17 \\
\hline Jamaica & 136 & 53 & 9 & 281 & 160 & 48 & 8 \\
\hline Japan & 17 & 27 & 12 & 27 & 21 & 3 & 1 \\
\hline Jordan & 126 & 7 & 24 & 145 & 188 & 6 & 20 \\
\hline Kenya & 73 & 6 & 35 & 82 & 123 & 3 & 17 \\
\hline Korea & 67 & 22 & 11 & 97 & 82 & 10 & 5 \\
\hline Kuwait & 104 & 19 & 24 & 143 & 155 & 13 & 17 \\
\hline Lao PDR & 61 & 2 & 16 & 63 & 81 & 1 & 7 \\
\hline Lebanon & 77 & 12 & 51 & 95 & 156 & 6 & 26 \\
\hline Madagascar & 55 & 4 & 55 & 59 & 115 & 1 & 20 \\
\hline Malawi & 73 & 8 & 26 & 85 & 110 & 4 & 12 \\
\hline Malaysia & 194 & 17 & 10 & 262 & 235 & 22 & 13 \\
\hline Mali & 60 & 4 & 51 & 65 & 120 & 2 & 20 \\
\hline Mauritania & 112 & 5 & 60 & 123 & 246 & 4 & 44 \\
\hline Mauritius & 122 & 1 & 36 & 124 & 209 & 1 & 29 \\
\hline
\end{tabular}




\begin{tabular}{|c|c|c|c|c|c|c|c|}
\hline Mexico & 59 & 79 & 6 & 152 & 66 & 31 & 2 \\
\hline Mongolia & 106 & 8 & 17 & 122 & 141 & 5 & 12 \\
\hline Morocco & 61 & 5 & 59 & 67 & 134 & 2 & 24 \\
\hline Mozambique & 88 & 7 & 22 & 101 & 128 & 4 & 13 \\
\hline Myanmar & 3 & 3 & 5 & 3 & 3 & 1 & 1 \\
\hline Nepal & 59 & 12 & 22 & 73 & 85 & 5 & 9 \\
\hline Netherlands & 100 & 6 & 57 & 112 & 215 & 4 & 38 \\
\hline New Zealand & 59 & 13 & 11 & 75 & 72 & 5 & 4 \\
\hline Nicaragua & 91 & 38 & 16 & 160 & 120 & 23 & 10 \\
\hline Niger & 40 & 10 & 71 & 48 & 96 & 3 & 19 \\
\hline Nigeria & 30 & 35 & 34 & 51 & 51 & 7 & 7 \\
\hline Norway & 70 & 6 & 43 & 79 & 131 & 3 & 20 \\
\hline Pakistan & 36 & 12 & 20 & 45 & 50 & 3 & 5 \\
\hline Panama & 199 & 12 & 7 & 246 & 226 & 15 & 9 \\
\hline Pap. New Guinea & 103 & 3 & 11 & 109 & 126 & 2 & 8 \\
\hline Paraguay & 48 & 19 & 8 & 66 & 55 & 6 & 2 \\
\hline Peru & 28 & 24 & 18 & 42 & 38 & 4 & 3 \\
\hline Philippines & 81 & 24 & 10 & 119 & 96 & 13 & 5 \\
\hline Poland & 50 & 3 & 60 & 54 & 112 & 1 & 20 \\
\hline Portugal & 74 & 4 & 67 & 79 & 173 & 2 & 33 \\
\hline Romania & 59 & 4 & 62 & 64 & 133 & 2 & 24 \\
\hline Rwanda & 36 & 23 & 50 & 52 & 71 & 5 & 12 \\
\hline Saudi Arabia & 72 & 20 & 21 & 101 & 103 & 10 & 10 \\
\hline Senegal & 69 & 5 & 69 & 75 & 163 & 2 & 31 \\
\hline Seychelles & 104 & 0 & 16 & 105 & 137 & 0 & 11 \\
\hline Sierra Leone & 39 & 14 & 54 & 50 & 81 & 4 & 14 \\
\hline Singapore & 356 & 16 & 10 & 470 & 427 & 38 & 24 \\
\hline South Africa & 50 & 10 & 29 & 60 & 78 & 3 & 10 \\
\hline Spain & 47 & 5 & 61 & 52 & 104 & 2 & 19 \\
\hline Sri Lanka & 82 & 17 & 16 & 109 & 108 & 9 & 9 \\
\hline St. Kitts \& Nevis & 123 & 21 & 2 & 173 & 129 & 17 & 2 \\
\hline Sweden & 76 & 8 & 48 & 87 & 148 & 4 & 24 \\
\hline Switzerland & 66 & 8 & 61 & 77 & 147 & 3 & 27 \\
\hline Tanzania & 63 & 6 & 26 & 70 & 96 & 2 & 11 \\
\hline Thailand & 90 & 14 & 13 & 115 & 113 & 8 & 8 \\
\hline Togo & 75 & 6 & 42 & 84 & 138 & 3 & 21 \\
\hline Trin. \& Tobago & 97 & 42 & 9 & 178 & 115 & 27 & 6 \\
\hline Tunisia & 93 & 3 & 75 & 99 & 234 & 2 & 46 \\
\hline
\end{tabular}




\begin{tabular}{|r|c|c|c|c|c|c|c|}
\hline Turkey & 44 & 9 & 46 & 52 & 85 & 3 & 13 \\
\hline Uganda & 32 & 4 & 58 & 35 & 70 & 1 & 12 \\
\hline United Kingdom & 58 & 12 & 53 & 71 & 119 & 4 & 20 \\
\hline Uruguay & 38 & 9 & 18 & 45 & 52 & 2 & 5 \\
\hline Venezuela & 48 & 50 & 10 & 96 & 58 & 16 & 3 \\
\hline Vietnam & 83 & 4 & 16 & 89 & 109 & 2 & 9 \\
\hline Yemen Rep & 73 & 7 & 13 & 83 & 91 & 3 & 6 \\
\hline Zambia & 91 & 5 & 17 & 100 & 122 & 3 & 10 \\
\hline Zimbabwe & 91 & 4 & 21 & 99 & 129 & 3 & 13 \\
\hline
\end{tabular}




\section{Appendix 1: How this Paper fits into the Literature}

This paper is similar to the many papers on Free Trade Areas (FTAs) and other regional trading arrangements, particularly its focus on their likely effects on trade and real income. Trade economists have tended to assume that the economic effects of eliminating political borders are the same as, not greater than, the economic effects of creating FTAs with the same geographic coverage. But empirical research has discovered recently that the existence of tariffs and other measurable trade barriers, or their removal within even the most serious of FTAs, in fact has a smaller effect on trade patterns than does the drawing of monetary and political borders. Yet the literature on the effects of currency unions on trade and output is small.

The paper links together several bodies of research that are already underway. The first is the effect of currency unions on trade. Until recently most economists gave short shrift to the idea that the elimination of exchange rate variability provides much of a stimulus to trade. The evidence in time series data is very weak. But there is now stronger evidence from cross-section data that the effect exists, particularly when a pair of countries goes beyond stabilizing the bilateral exchange rate between them, and actually adopts a common currency. Indeed it now seems that currency differences explain a small but significant part of the "home country bias" that has been observed in country's trade patterns even after holding constant for such geographic variables as bilateral distance, such social variables as linguistic differences, and such policy variables as tariffs. While currency unions eliminate a significant share of the home bias, there is still a lot remaining to be attributed to other aspects of national political borders.

The second relevant literature concerns the subject of trade and growth. There is a long and voluminous debate about whether trade promotes income, either in level form or rate-ofgrowth form. Many authors have found a statistical relationship between observed openness and observed income, even after holding constant for other determinants of growth such as convergence or catch-up, investment in physical capital, and investment in human capital. But there are concerns about reverse causality. The observed correlation between trade and growth may be because higher income leads to higher trade, rather than the other way around.

This paper uses a large data set of trade, growth and their determinants, among over 200 countries and smaller political units. At the first stage, we look at the determinants of bilateral trade. We use the gravity model to hold constant for such natural determinants of trade as size and proximity. ${ }^{40}$ Thus we can isolate statistically significant effects of a dummy variable that represents when a pair of units shares a common currency. Then, at the second stage, we are interested in a country's total trade as a share of its economy, rather than in bilateral trade per se, and the evidence that this measure of openness has an influence on output. We can get around the simultaneity problem by constructing a measure of a country's openness from the summation of its bilateral trade with its individual partners. When this measure is constructed to reflect only geographical and other plausibly exogenous determinants of bilateral trade, it becomes a good candidate for an instrumental variable with which to address the simultaneity problem. One may or may not believe that variations in trade associated with exogenous geographic determinants have the same sort of effects on output as the less-easily observed component of trade attributable to trade policy. But in any case, our focus here is on the effect that currency union has, and this we readily observe. We estimate the system in two steps, to identify both the effect of union on trade and the effect of trade on output. In addition, we offer a one-stage reducedform estimation of the effect that currency union has on output. 
The third area of literature that is relevant here concerns country size and output. Economies of scale are important in both the "New International Trade Theory" and the "New Growth Theory." In the imperfect substitutes model, for example, size and trade are both beneficial for the same reason: they make longer production runs economical and thus allow more varieties to be produced and consumed. But the basic point can also be seen in classical theories of trade as well. Assume that endowments of natural resources and other factors of production are not distributed evenly across the surface of the globe. A country large enough to include most of the major inputs can fare better than a country small enough to include only some. A small city-state will lack many natural resources, and will be dependent on foreign trade to get them. One view as to why the United States has been so successful over the last two centuries is that it is geographically large enough to include a bit of everything somewhere within its borders, and under the Interstate Commerce Clause of the Constitution, the fifty states can't impose interior trade barriers as can provinces or oblasts in the Canadian and Russian federations.

It is easy to see that we have to allow in our output equation for an effect whereby larger countries have better output prospects than small countries. Results from the gravity model say that for every one percent increase in the size of a unit, its trade with the rest of the world rises about .8 percent, so its ratio of trade to output falls by about .2 per cent. If a federation breaks into individual political units, the openness of each tends to be greater than the openness of the aggregate, if only because they trade with each other. If we failed to hold constant for size while looking for an effect of trade on output, we would have to expect to generate the prediction that smaller political units grow faster than larger ones. This prediction would obviously be false; in reductio ad absurdum, it would imply that we could all do better economically if we proclaimed the independent political sovereignty of our own households.

Moving from the hypothetical to the concrete, our data set in fact includes dependencies that belong to a political union with some larger country. Examples include islands in the Pacific or Caribbean that are part of France, the United Kingdom, or the United States. Clearly we would not want to estimate an equation that implied higher rates of output when units are treated individually merely because they have higher trade ratios than when they are aggregated (the same data) into a larger country observation.

Alesina, Spolaore and Wacziarg (1999) have developed a theory of country size and its economic benefits. Their model, which would serve well as the theoretical foundation for the present empirical paper, starts from the premise that the size of the market influences productivity. ${ }^{41}$ It of course follows immediately that larger political units will attain higher incomes than smaller ones. But another implication is that, to the extent that free trade allows countries to access foreign markets as readily as their own, openness is a substitute for size. A geographic unit can use either size (which may require political union with neighbors), or, failing that, trade with its neighbors, to attain the necessary economies of scale and thus income levels.

The authors obtain as one prediction that size and openness exhibit a negative interaction effect as determinants of income: the more you have of one, the less you need of the other. (They begin in a one-period model by establishing these effects on the level of income. They then extend the theory to the dynamic case, and obtain analogous effects on the rate of growth.) They find that these predictions are borne out by the data: size and openness have positive effects on output, while the product of the two variables has a negative effect.

Their most interesting theoretical and empirical finding turns the relationship around, taking as exogenous that the international trading regime has been increasingly open during 
some intervals over the last two centuries, such as the post war period, and increasingly closed over other intervals. The theory predicts that political units will find it necessary to aggregate into larger countries during the closed periods in order to attain economies of scale, and can afford the luxury of splitting up into smaller units during the open periods. This prediction too, regarding the number of countries in the world, is broadly confirmed by historical data.

Thus a central theme of this paper is that -- whether trade is conducted with residents of other countries, with residents of other political units with which one's own is federated, or with other residents of one's own political unit -- one's income depends positively on the intensity of economic interaction with other people. Trade in goods and services is probably the most important interaction, certainly the one most easily measured.

This is not to say that there are not countervailing factors, that size does not carry disadvantages, or that we would all necessarily be better off in a one-currency one-government world. Three sorts of countervailing factors come to mind, three respects in which large economies and intense interactions could be detrimental. The field of urban and regional planning contributes the first factor: congestion. If the increase in size comes through population or economic growth on a fixed amount of land, growth can run into diminishing returns. The fields of public finance and political economy contribute the second countervailing factor: public governance. If national governments exist for the purpose of supplying public goods, many of these may be more efficiently supplied in smaller political units, especially if preferences for public goods are heterogeneous. The field of open-economy macroeconomics contributes the third countervailing factor: monetary policy. Optimum currency area theory says that the advantages of monetary independence outweigh the advantages of fixed exchange rates when a geographic unit becomes sufficiently large that the intensity of economic interactions internally (trade, labor mobility, fiscal transfers) is high relative to the intensity of economic interactions with the rest of the world. This paper will not be further concerned with possible adverse effects of political and currency union. If they were strong enough, however, they would assert their presence through the long run growth data. 


\title{
Appendix 2: A Description of the Data Sets
}

We employ two data sets in this paper. The first is used to estimate the bilateral gravity models of trade, and thereby to model the effect of currency union on trade. The second is used to estimate the impact of trade on output.

The first (trade) data set consists of 41,678 bilateral trade observations spanning six different years $(1970,1975,1980,1985,1990$, and 1995). We are missing observations for some of the regressors so the usable sample is smaller for most purposes. All 186 countries, dependencies, territories, overseas departments, colonies, and so forth for which the United Nations Statistical Office collects international trade data are included in the data set. For convenience, we refer to all of these geographical units as "countries." The trade data are taken from the World Trade Database, a consistent recompilation of the UN trade data presented in Feenstra, Lipsey and Bowen (1997), augmented with data from the UN's International Trade Statistics Yearbook. This data set is estimated to cover at least $98 \%$ of all trade. The nominal trade values (recorded in thousands of American dollars), have been deflated by the American GDP chain price index. In this data set, there are 406 country-pair observations where there is trade between two members of a currency union. The currency unions are tabulated below.

\section{Table A1: Currency Unions in the Bilateral Trade Data Set}

\author{
Australia \\ Kiribati \\ Nauru \\ Tuvalu \\ Denmark \\ Faroe Islands (part of Denmark) \\ Greenland (part of Denmark) \\ ECCA \\ Anguilla (territory of UK) \\ Antigua and Barbuda \\ Dominica \\ Grenada \\ Montserrat (territory of UK) \\ St. Kitts and Nevis \\ St. Lucia \\ St. Vincent and the Grenadines

\section{France} \\ French Guiana (overseas department) \\ French Polynesia (overseas territory) \\ Guadeloupe (OD) \\ Martinique (OD) \\ Mayotte (territorial collectivity) \\ New Caledonia (OT) \\ Reunion (OD) \\ Saint Pierre and Miquelon (TC) \\ New Zealand \\ Cook Islands (self-governing) \\ Niue (self-governing) \\ CFA \\ Benin \\ Burkina Faso \\ Cameroon \\ Central African Republic \\ Chad \\ Comoros \\ (Republic of) Congo \\ Cote d'Ivoire \\ Gabon \\ Guinea-Bissau \\ Mali (post '84) \\ Niger \\ Senegal \\ Togo \\ UK \\ Falkland Islands (territory) \\ Gibraltar (territory) \\ Saint Helena (territory) \\ Ireland (pre '79) \\ USA \\ US Virgin Islands (territory) \\ British Virgin Islands (territory of UK) \\ Turks \& Caicos Isl. (territory of UK) \\ Bahamas \\ Bermuda (colony of UK) \\ Liberia \\ Panama \\ Barbados (? 2:1) \\ Belize (? 2:1) \\ We use the Penn World Table (PWT) 5.6 for population and real GDP per capita data, \\ filled in with data from the World Bank World Development Indicators (taken from the 1998 \\ WDI CD-ROM) where the former is missing (e.g., for 1995, where the Penn World Table data
}


set is unavailable). For location (used to calculate Great Circle distance and contiguity), official language, colonial background, and other such information, we use information taken from the CIA's web site. A number of regional free trade agreements are included in the FTA dummy: the EEC/EC; the Canada-US FTA; EFTA; the Australia/New Zealand closer economic relationship; the Israeli/US FTA; ASEAN; CACM; PATCRA; CARICOM; SPARTECA; and the Cartagena Agreement, using information at the WTO's web site.

The second macroeconomic data set consists of annual observations for 210 "countries" between 1960 and 1996 extracted from the 1998 World Bank World Development Indicators (WDI) CD-ROM, merged with data from the Penn World Table (PWT) Mark 5.6. For most purposes, the sample starts in 1970 and ends in 1990 or 1992 . A maximum of 7,803 observations is available (not all countries exist for the entire data sample). For both the WDI and the PWT data sets, we use all available observations (by which we mean the comprehensive set of years, countries, territories, colonies and other entities covered). There are numerous missing observations for variables of interest. The data set has been checked and corrected for mistakes. In this data set, there are 1,891 observations for countries that were members of a currency union. 


\section{Appendix 3: Sensitivity Analysis: Aggregate Openness and the Role of Tropical Geography}

As noted, we expect to get the sharpest estimate of the effect that a currency union has on a country's overall trade by estimating bilateral effects as in Table 1, and then aggregating across its bilateral trading partners. Nevertheless, it is of interest to try out a "short cut," and to see whether we can detect any effect of currency unions directly on a country's overall trade. For one thing, a failure to find an effect on overall trade would suggest the possibility of tradediversion, i.e., that much of the effect on bilateral trade with partners in the currency union comes at the expense of trade with non-partners. The implications for real income would be very different if this were true than if the trade created by the currency union were additional.

Our interest is in predicting a country's overall trade, so it is fortunate that many of the variables in the gravity model are either not inherently bilateral or can be converted out of bilateral form. The measures of domestic size and income, along with the dummy variables for landlocked countries and island states, are natural determinants of a country's overall openness. The core two bilateral gravity variables, bilateral distance and the size of the trading partner, can be aggregated by a single measure that has been labeled "remoteness": a GDP-weighted average of log distance from all trading partners. (New Zealand and Fiji are by this measure the remotest countries in the world, Liechtenstein and the Czech Republic the least remote.) To this list of determinates of overall openness we add the variable of central interest here: a dummy for whether the country is a member of some currency union. Again, without knowing whether a country's currency union is with a small island some distance away or a giant next-door neighbor, it should be harder to predict the effect on total trade.

Table A2 reports these estimates. The dependent variable here is the log of the ratio of a country's overall trade to GDP (consistent with the specification of the gravity model). Size, whether measured by population or land area or both, remains a very significant determinant of openness. Trade falls about .06 per cent, relative to GDP, for every one percent increase in land area, and also about .18 per cent for every one percent increase in population. Richer countries tend to be significantly more open than poor countries. Some, but not all, of this effect is attributable to the tendency of countries to reduce tariffs as they become richer: the coefficient on income per capita falls by half when holding constant the (significant) negative effect of a measure of tariff duties.

The core variable that we bring in from the gravity model, a GDP-weighted measure of remoteness from trading partners, shows a significant negative effect. Our preferred point estimate is -.12 so that for every one percent increase in distance from the rest of the world, trade falls by about .12 per cent. This is below typical estimates of the bilateral distance coefficient in the gravity equations, but the difference was to be expected. A country has to trade with somebody, so moving farther from all partners has less effect on bilateral trade with a given partner than would the same increase in bilateral distance with that partner alone. ${ }^{42}$ (An alternative is a population-weighted measure of remoteness, which avoids any conceivable problems regarding the endogeneity of trading partners' incomes. It shows an effect that is more significant and twice as large: .31.) The dummy variables for landlocked and island status show effects that are negative and usually significant. The variables for the rest of the world's GDP (and population) show significant positive effects (presumably capturing mainly growth over time).

The primary coefficient of interest is that on the currency union dummy. It is almost always highly significant, and in the neighborhood of $0.12-0.20$. The lower number is probably 
the more reliable one, since we trust better the results with time-effects. (Most countries are becoming gradually more open over time, and one would not want the currency union variable to appropriate the effect of that trend.) This point estimate suggests that, even without knowing with whom the currency union is formed, we can predict that overall trade for currency union countries will be higher by some 14 percent. $^{43}$

We see further evidence against trade diversion: the additional trade created by currency unions and political unions is not offset by a fall in trade with other countries. Rather there is a boost to the country's overall trade/GDP ratio.

Also of interest is the coefficient on the political union dummy. The coefficient is also statistically significant, and similar in magnitude: $0.12-0.41$, with again the lower estimate being the more reliable. When the trade duty variable is included alongside in the regression it has a significant negative effect, but does little to affect the coefficient on currency union and the coefficient on political union. ${ }^{44}$ In some runs, the coefficient on currency union (or political union) go up when some of the geographic variables are dropped -- land area, island, and landlocked. This presumably reflects that many of the currency union countries are small islands that would be very open as a result of their small size even if they did not have currency unions. These variables clearly belong in the equation.

It is of interest whether the better way to predict a country's openness is first to predict its bilateral trade patterns from the gravity model and then aggregate, as in the text, or to estimate an openness equation directly, which is the approach taken in Table A2. Goodness-of-fit statistics $\left(\mathrm{R}^{2}\right)$ for the openness equation are close to .6. As noted, the correlation between openness and the predicted openness that is aggregated from the gravity estimates is .72 (on 130 observations). While the two are not perfectly comparable, the aggregated gravity approach suggests an $\mathrm{R}^{2}$ of $.52\left(=.72^{2}\right)$, roughly equal to the $\mathrm{R}^{2}$ of the aggregate approach.

We are also interested in the effect of $(\log )$ openness on output, using instrumental variables from the aggregate approach. Our benchmark results are presented in Table A3. In Table A3 we use as instrumental variables many of the variables that we saw in Table A2 are useful determinants of aggregate openness: notably remoteness, landlocked status, and rest of world income, in addition to the union variables. The most important effect is to raise the coefficient on openness between four- and six-fold. As in Frankel-Romer and Irwin-Tervio, this is an almost embarrassingly strong openness effect to uncover in an instrumental variables estimation. The increase relative to the OLS estimate might be attributed to the benefits of economic interactions along gravity lines other than trade. However Hausman specification tests indicate that the differences between the OLS and IV estimates are not statistically significant.

Tables A2-A4 use the log of the ratio of trade to GDP, to correspond most closely to the gravity-based estimation in Table 1, in place of the level of openness in Tables 2-3. In Table A5, we use the level of openness in our output equation, but using aggregate instrumental variables (unlike Table 2). The coefficient on the level of openness is usually a bit lower, which is what one would expect. One should multiply the coefficient on openness by the level of openness (which averages 0.73 in the sample) to obtain an estimate comparable with the coefficient on the log of openness:

$$
\frac{d y}{d \log (T / Y)}=\frac{d y}{d(T / Y)} / \frac{d \log (T / Y)}{d(T / Y)}=(T / Y) \frac{d y}{d(T / Y)} .
$$


The one effect that is noticeably altered in Table A5 is the coefficient on size; when openness is measured in log form, the apparent effect of population rises in the instrumental variables estimation.

Hall and Jones (1999) have suggested that distance from the equator may belong in the income equation and Rodriguez and Rodrik (2000) have suggested that failure to include such variables may explain the apparent effect of gravity-instrumented trade. Table A4, adds distance from the equator. Although its coefficient has the hypothesized positive sign, it is not at all statistically significant, in either OLS or IV regressions, and its presence does not have a great effect on the other variables. In particular, it does little to diminish the strength of the effect of openness on income. We have also tried a measure indicating the percentage of a country's land mass located in the tropics, which Rodriguez and Rodrik argue matters for growth because, for instance, of the problem of malaria and other tropical diseases. The tropics variable is usually negative, as hypothesized. But again, it is of only marginal significance and in any case does not change the significant positive effect of openness on growth. Finally, we have tried continental dummies. One might expect that they would soak up much of the explanatory power of the geography, and would not leave enough juice to instrument for trade. But our finding is that the continental dummies leave the coefficient on trade unchanged. ${ }^{45}$ 
Table A2: The Effect of Currency Union on Aggregate Trade/GDP

\begin{tabular}{|c|c|c|c|c|c|}
\hline Currency Union & $\begin{array}{l}.12 \\
(.02) \\
\end{array}$ & $\begin{array}{l}.19 \\
(.03) \\
\end{array}$ & $\begin{array}{l}.10 \\
(.02) \\
\end{array}$ & $\begin{array}{c}.26 \\
(.04) \\
\end{array}$ & $\begin{array}{c}.14 \\
(.02) \\
\end{array}$ \\
\hline Political Union & $\begin{array}{c}.12 \\
(.03)\end{array}$ & $\begin{array}{c}.41 \\
(.05)\end{array}$ & $\begin{array}{l}.19 \\
(.03)\end{array}$ & $\begin{array}{c}.04 \\
(.02)\end{array}$ & $\begin{array}{c}.13 \\
(.03)\end{array}$ \\
\hline $\begin{array}{r}\text { Log Real GDP } \\
\text { per Capita }\end{array}$ & $\begin{array}{c}.12 \\
(.01) \\
\end{array}$ & $\begin{array}{c}.06 \\
(.01) \\
\end{array}$ & $\begin{array}{l}.12 \\
(.01) \\
\end{array}$ & $\begin{array}{l}.25 \\
(.02) \\
\end{array}$ & $\begin{array}{l}.15 \\
(.01) \\
\end{array}$ \\
\hline Log Population & $\begin{array}{l}-.19 \\
(.01) \\
\end{array}$ & $\begin{array}{l}-.17 \\
(.01) \\
\end{array}$ & $\begin{array}{c}-.23 \\
(.003) \\
\end{array}$ & $\begin{array}{l}-.07 \\
(.03)\end{array}$ & $\begin{array}{l}-.17 \\
(.01)\end{array}$ \\
\hline Log Land Area & $\begin{array}{l}-.06 \\
(.01)\end{array}$ & $\begin{array}{l}-.08 \\
(.01) \\
\end{array}$ & & & $\begin{array}{l}-.05 \\
(.01)\end{array}$ \\
\hline Island & $\begin{array}{l}-.10 \\
(.02) \\
\end{array}$ & $\begin{array}{l}-.02 \\
(.03) \\
\end{array}$ & & & $\begin{array}{l}-.07 \\
(.02) \\
\end{array}$ \\
\hline Landlocked & $\begin{array}{l}-.04 \\
(.02)\end{array}$ & $\begin{array}{c}.01 \\
(.03) \\
\end{array}$ & & & $\begin{array}{l}-.04 \\
(.02)\end{array}$ \\
\hline Remoteness & $\begin{array}{l}-.15 \\
(.03) \\
\end{array}$ & $\begin{array}{l}.06 \\
(.05) \\
\end{array}$ & $\begin{array}{l}-.27 \\
(.03) \\
\end{array}$ & $\begin{array}{l}-.67 \\
(.15) \\
\end{array}$ & $\begin{array}{l}-.12 \\
(.03)\end{array}$ \\
\hline $\begin{array}{r}\text { Log RoW Real } \\
\text { GDP }\end{array}$ & $\begin{array}{c}.37 \\
(.02) \\
\end{array}$ & $\begin{array}{l}.19 \\
(.04) \\
\end{array}$ & $\begin{array}{c}.41 \\
(.02)\end{array}$ & $\begin{array}{l}.25 \\
(.03) \\
\end{array}$ & $\begin{array}{l}2.89 \\
(.15)\end{array}$ \\
\hline $\begin{array}{r}\text { Log Import } \\
\text { Tariff rate } \\
\end{array}$ & & $\begin{array}{l}-.06 \\
(.01) \\
\end{array}$ & & & \\
\hline $\begin{array}{r}\text { Number of } \\
\text { Observations }\end{array}$ & 4236 & 1777 & 4236 & 4236 & 4236 \\
\hline $\mathbf{R}^{2}$ & .57 & .60 & .55 & .88 & .59 \\
\hline RMSE & .416 & .396 & .423 & .228 & .409 \\
\hline & & & & $\begin{array}{l}\text { Country } \\
\text { Fixed } \\
\text { Effects }\end{array}$ & $\begin{array}{c}\text { Year } \\
\text { Fixed } \\
\text { Effects } \\
\end{array}$ \\
\hline
\end{tabular}

Regressand is log of trade/GDP, PWT.

Intercepts/fixed effects not reported.

Robust standard errors recorded in parentheses. 
Table A3: The Effect of Aggregate Openness on Output

\begin{tabular}{|r|c|c|c|c|c|c|c|}
\hline & OLS & IV & OLS & IV & OLS & IV & IV \\
\hline Log Openness & .61 & 2.17 & .60 & 2.08 & .19 & .34 & .36 \\
& $(.21)$ & $(1.00)$ & $(.21)$ & $(.96)$ & $(.07)$ & $(.20)$ & $(.20)$ \\
\hline Log Population & .23 & .40 & .16 & .32 & .12 & .13 & .13 \\
& $(.08)$ & $(.12)$ & $(.08)$ & $(.12)$ & $(.03)$ & $(.04)$ & $(.04)$ \\
\hline Log Area & -.09 & .06 & -.07 & .08 & -.07 & -.05 & -.05 \\
& $(.07)$ & $(.14)$ & $(.07)$ & $(.13)$ & $(.02)$ & $(.03)$ & $(.03)$ \\
\hline Log 1970 & & & & & .75 & .75 & .75 \\
GDP/capita & & & & & $(.05)$ & $(.05)$ & $(.05)$ \\
\hline Investment & & & & & .019 & .018 & .017 \\
Ratio & & & & & $(.005)$ & $(.005)$ & $(.005)$ \\
\hline Population & & & & & -.04 & -.045 & -.04 \\
Growth Rate & & & & & $(.05)$ & $(.049)$ & $(.05)$ \\
\hline Primary & & & & & .002 & .001 & .001 \\
Schooling & & & & & $(.001)$ & $(.002)$ & $(.002)$ \\
\hline Secondary & & & & & .005 & .006 & .005 \\
Schooling & & & & & $(.002)$ & $(.002)$ & $(.002)$ \\
\hline Currency Union & & & -.76 & -.73 & & & -.05 \\
& & & $(.24)$ & $(.27)$ & & & $(.09)$ \\
\hline $\begin{aligned} \text { Number of } \\
\text { Observations }\end{aligned}$ & 114 & 114 & 114 & 114 & 106 & 106 & 106 \\
\hline $\mathbf{R} 2$ & .11 & & .16 & & .94 & .94 & .93 \\
\hline RMSE & 1.02 & 1.81 & .99 & 1.18 & .28 & .28 & .29 \\
\hline
\end{tabular}

Regressand is log of Real GDP/capita in 1990, PWT.

Intercepts not reported. Robust standard errors recorded in parentheses.

Instrumental variables for log openness: Currency Union, Political Union, Log(Pop), $\log (\operatorname{area})$, Landlocked, Remoteness, Log(RoW GDP). 
Table A4: Aggregate Openness and Output; the Role of the Equator

\begin{tabular}{|r|c|c|c|c|c|}
\hline & OLS & IV & IV $^{*}$ & IV & IV $^{*}$ \\
\hline Log Openness & .20 & .36 & .50 & .39 & .53 \\
& $(.07)$ & $(.21)$ & $(.20)$ & $(.20)$ & $(.20)$ \\
\hline Log Population & .12 & .14 & .15 & .13 & .15 \\
& $(.03)$ & $(.04)$ & $(.03)$ & $(.04)$ & $(.03)$ \\
\hline Log Area & -.07 & -.05 & -.03 & -.04 & -.03 \\
& $(.02)$ & $(.03)$ & $(.04)$ & $(.03)$ & $(.04)$ \\
\hline Log 1970 & .75 & .76 & .76 & .76 & .76 \\
GDP/capita & $(.05)$ & $(.05)$ & $(.06)$ & $(.05)$ & $(.06)$ \\
\hline Investment Ratio & .019 & .017 & .016 & .017 & .015 \\
& $(.005)$ & $(.005)$ & $(.006)$ & $(.006)$ & $(.006)$ \\
\hline Population & -.04 & -.05 & -.06 & -.05 & -.06 \\
Growth Rate & $(.05)$ & $(.06)$ & $(.06)$ & $(.06)$ & $(.06)$ \\
\hline Primary Schooling & .002 & .001 & .001 & .001 & .001 \\
& $(.001)$ & $(.002)$ & $(.002)$ & $(.002)$ & $(.002)$ \\
\hline Secondary & .006 & .006 & .006 & .005 & .006 \\
Schooling & $(.002)$ & $(.002)$ & $(.003)$ & $(.002)$ & $(.003)$ \\
\hline Currency Union & & & & -.06 & -.07 \\
& & & & $(.09)$ & $(.10)$ \\
\hline Log distance to & -.006 & -.015 & -.022 & -.017 & -.026 \\
equator & $(.034)$ & $(.036)$ & $(.037)$ & $(.037)$ & $(.039)$ \\
\hline $\mathbf{R}^{2}$ & .94 & .94 & .93 & .94 & .93 \\
\hline RMSE & .28 & .29 & .30 & .29 & .31 \\
\hline & & & & &
\end{tabular}

Intercepts not reported. Robust standard errors recorded in parentheses.

Number of Observations $=106$.

Instrumental variables for log openness: Currency Union, Political Union, Log(Pop), Log(Area), Landlocked, Remoteness, Log(RoW GDP).

* IVs are Currency Union, Political Union, Log(Pop), Landlocked, Remoteness. 
Table A5: Sensitivity Analysis: the Level of Aggregate Openness and Output

\begin{tabular}{|r|c|c|c|c|c|c|}
\hline & OLS & IV & IV & OLS & IV & IV \\
\hline Level Openness & .69 & 1.58 & 1.50 & .25 & .41 & .43 \\
& $(.21)$ & $(.84)$ & $(.79)$ & $(.07)$ & $(.12)$ & $(.11)$ \\
\hline Log Population & .18 & .20 & 0.13 & .10 & .10 & .10 \\
& $(.08)$ & $(.09)$ & $(.10)$ & $(.03)$ & $(.03)$ & $(.03)$ \\
\hline Log Area & -.06 & .05 & .06 & -.05 & -.03 & -.03 \\
& $(.08)$ & $(.15)$ & $(.14)$ & $(.02)$ & $(.04)$ & $(.04)$ \\
\hline Log 1970 & & & & .74 & .73 & .73 \\
GDP/capita & & & & $(.05)$ & $(.05)$ & $(.05)$ \\
\hline Investment Ratio & & & & .017 & .015 & .014 \\
& & & & $(.006)$ & $(.006)$ & $(.007)$ \\
\hline Population & & & & -.04 & -.04 & -.04 \\
Growth Rate & & & & $(.05)$ & $(.05)$ & $(.05)$ \\
\hline Primary Schooling & & & & .002 & .001 & .001 \\
& & & & $(.001)$ & $(.002)$ & $(.002)$ \\
\hline Secondary & & & & .006 & .007 & .007 \\
Schooling & & & & $(.002)$ & $(.002)$ & $(.002)$ \\
\hline Currency Union & & & -.75 & & & -.05 \\
\hline $\begin{array}{r}\text { Number of } \\
\text { Observations }\end{array}$ & 114 & 114 & 114 & 106 & 106 & 106 \\
\hline R ${ }^{2}$ & .11 & .01 & .08 & .94 & .94 & .94 \\
\hline RMSE & 1.02 & 1.08 & 1.04 & .27 & .28 & .28 \\
\hline
\end{tabular}

Intercepts not reported. Robust standard errors recorded in parentheses.

Instrumental variables for openness: Currency Union, Political Union, Log(Pop), Log(area), Landlocked, Remoteness, Log(ROW GDP).

Coefficients and standard errors for openness have been multiplied by 100 . 


\section{Endnotes}

1 Surveys of the literature are available in Edison and Melvin (1990) and Goldstein (1995).

2 See also Frankel (1997). In these data sets, however, the negative effect disappears after 1980.

3 This result is somewhat higher than that in the literature, which usually finds the estimates to be in the range of 0.6 to 0.8 , as surveyed and estimated in Frankel (1997, p. 70-72).

$4=\exp (0.7)$

5 as $\exp (1.2)=3.3$

$6=\exp (0.4)$.

7 For instance, land area shows a very significant effect; a one percent increase in geographical size reduces trade by around 0.16 per cent, analogously to the negative effect that the population measure of size has on trade, holding constant also for economic size (GDP). Landlocked status also matters; a country lacking access to the sea suffers an adverse trade effect of over 40 percent $(=\exp (-0.36))$. The island effect, on the other hand, is insignificant. 8 See McCallum (1995) or Helliwell (1998) for a quantity-based measure of trade integration, and Engel and Rogers $(1994,1997)$ for a price-based measure.

9 We can reproduce this result in our data set, by drop from the gravity equation all variables that tend to go with nationhood -- currency, language, trade policy -- leaving only the political union variable. When we do so, the home bias effect is estimated at McCallum's level of twenty (the estimated coefficient on political union is 3, and $\exp (3.0)=20)$.

10 We have tried interacting the currency dummy with the other variables, but the results were not in general statistically significant, and are not reported here. Log linearity still seems an appropriate specification. It implies an interactive or multiplicative effect on trade when translated from logs to levels. The equation automatically has the implication that the formation of a currency union with a country that would be a major trading partner in any case (for example, because it is a large neighbor), will have a bigger dollar effect on total trade than the formation of a currency union with a country that is small and far away.

11 E.g., Grossman and Helpman (1991a, 1991b), Helpman (1988), Helpman and Krugman (1985).

12 Examples include Michaely (1977), Krueger (1978), Feder (1982), Kohli and Singh (1989), Romer (1989), Quah and Rauch (1990), DeLong and Summers (1991), Dollar (1992), Edwards (1993a), and van den Berg and Schmidt (1994). Edwards (1993b) and Rodrik (1993) survey the literature.

13 For example, Feder (1982) regresses growth rates for 31 semi-industrialized countries over 1964-1973 against three variables: investment as a share of income, the rate of growth of the labor force, and the rate of growth of exports (multiplied by exports as a share of income). The coefficient on the last variable is highly significant statistically. Similarly, Edwards (1993, pp.9-11) regresses the rate of growth of total factor productivity on two measures of openness (total trade as a percent of GDP, and total tariff revenue as a percentage of trade) along with some other variables, and finds that "in every regression the proxies for trade distortions and openness are highly significant."

14 Levine and Renelt (1992) reach similar conclusions.

15 Indeed, if an equation features a regression of GDP against exports (or the rates of change thereof), the simultaneity problem is clear: a correlation may emerge simply because exports are a component of GDP, rather than because of any extra contribution that trade makes to growth.

16 E.g., DeLong and Summers (1991), Fischer (1991, 1993), Dollar (1992), Easterly (1993), Edwards (1993), Sachs and Warner (1995) and Harrison (1996). Rodriguez and Rodrik (2000) offer methodological critiques of many of these papers and conclude that the case is still open.

17 From the viewpoint of a small individual country, the outputs of its trading partners are exogenous as well. For a study like this that seeks to explain output for a cross-section of countries, one does not wish to treat GDPs of trading partners as exogenous, even if the domestic country is small. But if the standard factor-accumulation terms in a output regression (labor force growth, investment, and education) can be treated as exogenous in the domestic country, then they can also be considered exogenous in trading partners.

18 Frankel and Romer use samples ranging from 98 to 150 countries and find that the coefficient on openness in an output equation goes from 0.8 in an OLS regression to over 2.0 with instrumental variable estimates, and remains statistically significant. These output equations do not attempt to control for initial income or factor accumulation variables. The implication is that when openness goes from zero to 200 (from a stylized Myanmar to a stylized Singapore), the effect is to multiply income more than four-fold.

19 Barro (1991), Barro and Sala-i-Martin (1992), and Mankiw, Romer, and Weil (1992). 
20 At one extreme, the hypothesis of unconditional convergence would predict that only lagged income is necessary to predict future income. At the other extreme, the hypothesis that countries are always in their Solow neoclassical growth steady-state equilibrium would predict that lagged income has no effect. Neither polar case seems likely. 21 When controls were included in the working paper version of Frankel and Romer, the estimate of $\beta$ were smaller by as much as a factor a factor of six ( $\beta$ was estimated to be .34 using IV). The difference in magnitude can be explained by some combination of: a) induced effects of openness on factor accumulation, and b) the interpretation of the coefficient in the stripped-down version as a long-run equilibrium effect. Frankel and Romer estimated $\delta$ to be .7, implying that the long run effect of openness was .34/(1-.7).

22 In the most stripped-down version (not reported), a simple OLS regression of GDP per capita against openness produces a borderline-significant coefficient estimate of .3. But as noted early in this paper, it is important at a minimum to hold constant for country size, lest we falsely give encouragement to secessionist movements around the world.

23 It is also worth holding constant for the initial level of GDP if the results are to be useful for countries policy changes.

24 These estimates are not very different when the equation is run with the log of openness, as can be seen in the appendix.

25 In the version with controls, the level of population enters with a (still statistically significant) coefficient estimated at around 0.1 . This OLS estimate suggests that the largest country in the sample derives a per capita income advantage relative to the mean country of around 54 per cent $[=0.1(14.0-8.6)]$, and the smallest derives a disadvantage relative to the mean of 49 per cent $[=0.1(8.6-3.7)]$.

26 Ghosh, Gulde and Wolf (1997) find that currency board countries on average have higher growth than other countries: a difference of 1.8 percent per annum, whether in an equation that conditions on such other variables as initial income, investment, and human capital, or in unconditional averages. The authors start from the premise that the effects, if any come, via lower inflation. (In our sample, the mean inflation rate is lower among currency union members than among the rest of the sample, again as hypothesized under the credibility channel, but the difference is not significant at the $90 \%$ level. This difference is even less significant for the currency board countries in our sample. Growth appears significantly lower for the currency union countries, and higher for the currency board countries.)

27 These results are insensitive to adding the log of area as a measure of country size, though adding area turns the population coefficients positive. Adding openness to the equation, suitably instrumented, makes all the currency union terms insignificant.

28 We hope to extend Table 3 to interact the customs union variable with a more complete estimate of the partners' natural importance for trade. We would like to be able to use such an equation as an alternate way of making predictions such as those in Table 4, a way that does not depend on the two-step approach.

29 More precisely, one would expect if the credibility channel held that currency unions would promote output to the extent that the partner currency was particularly stable in value. We tried entering into the output equation a variable that interacts currency union status with the inflation rate of the anchor partner, relative to the world inflation rate. The effect is positive as hypothesized, but not at all significant statistically.

30 Of course, our framework does not rule out the idea that other economic interactions along geographic lines, such as investment, communication, and movement of people, could constitute part of the output effect, rather than exclusively trade.

31 One can do a rough calculation to predict the effect on the average country of adopting the dollar. Total US trade is $14 \%$ of world trade and non-U.S. trade is $86 \%$ of world trade (1997). So define an average country as one where the US is the partner in $14 \%$ of its trade. Thus, for an average country, if "dollarization" triples trade with the U.S., then it increases its total trade by about 28 percent $\left(3^{*} .14+.86=1.28\right)$. That assumes no trade-diversion, on the one hand, and no other substantial "dollarized" countries, on the other hand. In our sample, mean openness is 36 per cent. Thus we predict that "dollarization" for an average country would raise its openness ratio by about 10 points $(=.28 * 36)$. This is close to the .14 estimate for the effect of a generic currency union that we find in the appendix using an aggregate openness equation. As in the appendix we find that the predicted effect on income is roughly four percentage points of output.

32 A possible alternate approach would be to take the gravity-predicted trade shares as the base, rather than the actual trade shares.

33 This paper was written before Greece was admitted to EMU. 
34 One could easily extend Table 4 to estimate (for each country in our sample), the predicted effects on trade and output of adopting the currency of a given country's biggest trading partner or the currency of its closest neighbor (even if those are not the dollar or euro).

35 We hope in future work to estimate the effects of redrawing some sensitive political boundaries, in parallel with our predictions here regarding monetary boundaries. What is the economic benefit from political unions, such as the reunification of Germany? If the European Union goes all the way to full political union, will this provide a further boost to output? How high an economic price would secessionist regions have to pay for independence -- Quebec, Puerto Rico, Catalonia, Brittany, and Scotland? Would the price of independence be especially high for Chechnya or Tibet, because they would lose direct access to the sea? Are the constituent parts of recently-terminated federations already paying an economic price - the former Soviet Union, Czechoslovakia, and Yugoslavia? How much difference would it make economically to the emerging Palestinian entity if it were granted a corridor linking Gaza to the West Bank? How much difference would it make to Bolivia if it were granted a corridor to the Pacific? Clearly many factors do and should enter into decisions how to draw political and monetary borders. Even putting aside the myriad political factors, which in most cases are understandably sensitive and emotional for the parties most directly affected, the economics alone are complex. But any such decisions should be informed by whatever empirical evidence is available on likely implications for trade and output of the regions in question.

36 On the one hand, large countries might begin to feel dis-economies of scale: congestion, supra-optimal currency area size, or over-centralization of public goods provision. On the other hand, very small countries or dependencies are the ones that are in greatest need of economies of scale, whether through a Free Trade Area, currency union, political union, or territorial expansion.

37 Frankel and Romer (1999, p. 385,388) and Rodriguez and Rodrik (2000). Our view is that these three "citystates" are important examples of the sort of small units that most often consider giving up currency independence, and that there is little reason to single them out for omission. But given the concerns of others we thought it nonetheless worthwhile to test and report whether the results depend on their inclusion.

38 When we drop the same three countries in the estimation technique that we use in the appendix (which uses individual instruments such as remoteness), the coefficient on openness again retains its significance for the specification that conditions only on size, but loses its significance in the specification that conditions also on other variables.

39 Historical evidence regarding the formation and dissolution of federations might offer a clue regarding lags. Within five years of the re-unification of East and West Germany in 1989, intra-German trade concentration increased four-fold. Similarly, after the break-ups of the Austro-Hungarian Empire, Federation of Malaya, and Czechoslovakia, trade patterns among the constituent parts in each case shifted away from one another within a few years.39 In each case, the introduction of different currencies may explain part of the effect. In each case, however, the impact after five years was far less than the total twenty-fold home bias effect estimated from crosssection data. The implication is that it takes many years to reach the full effect.

40 The results of one early gravity study were reported in Linnemann (1967). The theoretical rationale for the idea that bilateral trade depends on the product of country size comes from, e.g., Helpman (1987) and Helpman and Krugman (1985, section 1.5). Frankel (1997) elaborates, gives many further references and applies the gravity model to regional trading arrangements. The point there, that FTAs are more likely to be beneficial if they are undertaken with natural trading partners, is analogous to the point of the present paper regarding the decision with whom one forms a currency union.

41 They posit a production function where a region's output is higher if it can buy imperfectly-substitutable intermediate inputs freely from lots of other regions. One could imagine alternatives where the gains from trade originated in imperfect substitution in consumption, or more classical determinates of comparative advantage. 42 This effect shows up in the standard gravity model in the form of a positive effect of a country's overall remoteness on all its bilateral trade, alongside the usual negative coefficient on bilateral distance. Frankel (1997, p.143).

43 How does the magnitude of the currency union effect estimated in Table A2 compare to the appropriately translated version of the effect estimated in Table 1? Because the average currency union member in our sample undertakes $24.9 \%$ of its trade with other members of the currency union, the three-fold boost estimated earlier from the gravity model implies a bigger effect than the estimated 14 per cent $(.249 * 1.2=.3>.14)$. The three plausible explanations for the discrepancy are (i) some amount of trade diversion, (ii) an errors-in-variables interpretation of the results for the effect of currency unions on overall openness, since the effect is better-specified in the gravity equation, or (iii) the perils of averaging across a heterogeneous group of countries.

$44.19-.20$ and .39-.41, respectively, without year effects. 
45 This is in the equation that controls for initial income and other factors. The continental dummies make more of a difference, reducing the openness coefficient, when no attempt is made to control for initial income and other factors. 